\title{
AN EVALUATION OF CRITICAL KNOWLEDGE AREAS FOR MANAGING THE COVID-19 PANDEMIC
}

\author{
Wala Abdalla, Suresh Renukappa and Subashini Suresh \\ Faculty of Science and Engineering, \\ University of Wolverhampton, \\ Wolverhampton WV1 1LY, UK.
}

\begin{abstract}
Purpose

The ability to manage the COVID-19 pandemic is contingent upon the ability to effectively manage its heterogeneous knowledge resources. Knowledge mapping represents a great opportunity to create value by bringing stakeholders together, facilitating comprehensive collaboration and facilitating broader in-depth knowledge sharing and transfer. However, identifying and analysing critical knowledge areas is one of the most important steps when creating a knowledge map. Therefore, the aim of this paper is to appraise the critical knowledge areas for managing COVID-19, and thereby enhance decision-making in tackling the consequences of the pandemic.
\end{abstract}

\section{Design/methodology/approach}

The methodological approach for this study is a critical literature review, covering publications on knowledge management, knowledge mapping and COVID-19. EBSCOhost, PubMed, Scopus, Science Direct, TRID, Web of Science and Wiley Online Library were searched for full text, peer-reviewed articles written in English that investigated on critical knowledge areas for managing the spread of COVID-19. After full screening, 21 articles met the criteria for inclusion and were analysed and reported.

\section{Findings}

The study revealed seven critical knowledge areas for managing the COVID-19 pandemic. These are: cleaning and disinfection; training, education and communication; reporting guidance and updates; testing; infection control measures, personal protective equipment; and potential COVID-19 transmission in health and other care settings. The study developed a concept knowledge map illustrating areas of critical knowledge which decision-makers need to be aware of.

\section{Theoretical implications}

The study advances the literature on knowledge management and builds a theoretical link with the management of public health emergencies. Additionally, the findings support the theoretical position that knowledge maps facilitate decision-making and help users to identify critical knowledge areas easily and effectively.

\section{Practical implications}

Providing decision-makers with access to key knowledge during the COVID-19 pandemic seems to be crucial for effective decision-making. This study has provided insights for the professionals and decision-makers identifying the critical knowledge areas for managing the COVID-19 pandemic.

\section{Originality/value}


This study fills gaps in the existing literature by providing an explicit representation of knowhow for managing the COVID-19 pandemic. This paper uses an objective and qualitative approach by reviewing related publications, reports and guidelines in the analysis. The concept map illustrates the critical knowledge areas for managing the COVID-19 pandemic.

Keywords: COVID-19, coronavirus, concept map, knowledge areas, knowledge mapping.

\section{Introduction}

The novel coronavirus (SARS-CoV-2) or COVID-19 is a public health emergency of international concern that has had a large-scale global effect and has compelled people to significantly alter their lifestyles (Zhou et al., 2020a; Khowaja et al., 2021). As of 15th November 2021, COVID-19 had been transmitted to 253,163,330 people resulting in $5,098,174$ verified deaths (WHO, 2021). In addition, the pandemic has seriously affected economic and social development (Zhou et al., 2020a). Over 23 months into the pandemic, it remains a global challenge to identify the presence and spread of the virus.

The World Health Organization (WHO) recommended that governments worldwide should quickly intensify active surveillance to identify infected individuals to allow rapid isolation and quarantine (Kummitha, 2020). Meanwhile, Weintraub et al. (2021) noted that public health leaders are recommending a combination of nonpharmaceutical interventions in an attempt to slow the transmission of the novel coronavirus. However, this alone will not end the transmission of COVID-19. Therefore, a safe and effective vaccine is a critical component in reducing COVID-19-related illnesses, hospitalisations and deaths and in restoring the global economy (Khowaja et al., 2021; Weintraub et al., 2021). Scientists around the globe are trying to develop novel vaccines and effective therapies to reduce the spread of COVID-19 (Mortazavi et al., 2021). To address these challenges, knowledge is increasingly being accessed and shared across different countries, organisations, functional departments, and among professionals. However, this knowledge interdependence creates new management challenges resulting from the risks and difficulties of knowledge transactions across boundaries. Providing decision makers with access to key tacit and explicit knowledge during the COVID-19 pandemic seems to be critical for effective decision-making.

On the other hand, smart technologies and big data analytics have played an important role in identifying transmission of the virus and in offering insights into the data necessary for prevention and control measures (Kummitha, 2020; Zhou et al., 2020a). Agbehadji et al. (2021) noted the significant contributions of adopting artificial intelligence (AI) and big data analytics in facilitating contact tracing. For example, by creating an epidemic intelligence dashboard through data analytics and a visualisation tool, relevant data can be easily located, accessed and converted into business intelligence that is ready for sharing among healthcare professionals in real-time. This can help healthcare professionals to improve their understanding of the crisis, create powerful leverage in terms of policy/strategic interventions, and allow informed decisions to be made to cope with the pandemic. Additionally, Shi et al. (2021) noted the emergence of AI-based technologies for medical image acquisition and analysis of COVID-19 cases. This will help to automate scanning and detection procedures, especially in the area of reducing contact between patients and frontline hospital workers. Gombos et al. (2021) observed that, in times of epidemics, it is essential to translate scientific findings into digestible information for government policy makers who have only a short time in which to make critical decisions. Wiig (1997) argued that knowledge will be the key to success in the twenty-first century, due to the fact that it generates a value for organisations 
when it is employed. Therefore, the availability of data, information and knowledge is very important in managing the COVID-19 pandemic.

Considering the characteristics of strong infectivity, a long incubation period and uncertain detection of COVID-19 (Zhou et al., 2020a), combined with the constraints of logistics, mutations and vaccine acceptance (Khowaja et al., 2021), there is a dire need for scientific and technological support in the global pandemic response, not only to control and prevent the spread of the virus, but also to provide recommendations regarding safety guidelines and hygiene, to improve people's immune system functioning and also to help improve the circumstances in which people are living during the pandemic (Khowaja et al., 2021; Zhou et $a l ., 2020 \mathrm{a})$. One way to accomplish the aforementioned task is to manage COVID-19-related knowledge. Hence, the ability to manage COVID-19 is contingent upon the ability to manage the related knowledge resources effectively. Jallow et al. (2020) recommended in their study that, to address the effects of COVID-19, knowledge should increasingly be accessed and shared across sectors and national boundaries. Therefore, there is a need for cross-sector collaboration to capture and share best and worst practices related to managing COVID-19 and the concomitant issues.

Market complexity as well as internal organisational trends and developments have changed the ways in which firms organise their activities, locally as well as globally, both in terms of tangible and intangible assets (Michailova and Nielsen, 2006; Drucker, 1993). Manesh et al. (2020) noted that, due to increased competitive pressure, modern organisations tend to rely on knowledge and its exploitation to sustain a long-term advantage. The challenge of managing knowledge is a daunting task for any organisation. An organisation's knowledge resources are complex and multifaceted, ranging from tacit components to knowledge that is explicitly represented and understood.

Present and future societies are based on knowledge (Drucker, 1988). Chaudhuri et al. (2020) stated that in this knowledge era, the key determinant for the sustainability and growth of any organisation, sector or country is based on their ability to manage their knowledge resources. Likewise, Ferreira et al. (2018) noted that the current knowledge economy requires companies to create new business structures and new concepts for the management of their resources to remain competitive. Knowledge has been and continues to be the key to success and competitive advantage for all organisations (Ramona and Alexandra, 2019). Michailova and Nielsen (2006) noted that assertions about the importance of knowledge, and especially tacit knowledge, for constituting competitive advantage, organisational performance and organisational success have been put forward by, among others, Nonaka and Takeuchi (1995), and Grant (1996). Additionally, Carayannis et al. (2017) noted that there is increasing interest in adopting systems to help organisations retain and transfer knowledge while, at the same time, creating value. This process involves ensuring that the right user has the right knowledge and uses this knowledge to improve organisational performance (Jennex et al., 2009; Kruesi et al., 2020).

Such systems rely on a precise understanding of Knowledge Management (KM) processes and, specifically, an understanding of how knowledge is created, shared/transferred, acquired, stored/retrieved, and applied throughout an organisational system. Suresh and Egbu (2008) noted that KM consists of distinct but interrelated processes that are not linear but can be iterative. The authors noted that KM can be defined as "a process by which knowledge is identified, captured, codified, stored, disseminated (shared/ transferred), implemented (adapted, transformed, synthesised) and its impact measured for the benefit of an organisation". 
For professionals dealing with the COVID-19 pandemic, it can prove difficult to access core knowledge for highly knowledge-intensive activities, such as public health problem-solving, decision-making, etc. This situation calls for knowledge mapping to increase the visibility of knowledge sources to facilitate and accelerate the process of locating relevant expertise or experience. It is now widely accepted that the challenge of $\mathrm{KM}$ is to understand how to create practical solutions to support individuals, groups and organisations as they generate and capture multi-faceted knowledge so as to suit the particular requirements of the context of their application (Despres and Chauvel, 2000). As Skyrme and Amindon (1997) have noted, KM has been most commonly researched within organisations, and knowledge mapping remains an emergent research area.

Increasing attention has been paid to knowledge maps as an important subfield of KM; they are recognised as playing an imperative role (Balaid et al., 2016). Knowledge mapping is a novel analysis tool that combines theories and methods from mathematics, graphics and other disciplines to reveal the core structure, developmental history, hotspots and integral knowledge architecture of a discipline (Liang et al., 2018). Renukappa and Egbu (2007) remarked that knowledge mapping is a field within KM that aims to optimise the efficient and effective use of an organisation's sustainability-related knowledge. Hence, a knowledge map will effectively foster, capture, generate, transfer, codify, store and utilise knowledge (Balaid et al., 2016; APQC, 2018b). Mapping COVID-19-related knowledge allows knowledge resources, ideas and links to be represented visually; thus, it aids stakeholders in identifying and locating what knowledge is critical, where it resides and how it flows (APQC, 2018b).

However, despite the evident need to map knowledge related to COVID-19, and the significant benefits and implications for controlling the spread of the virus and enhancing decisionmaking, the current literature indicates that there is an exclusive focus on the use of technology to apply restrictions and lockdown strategies, while ignoring one of the most critical elements for tackling the spread of the virus and informing and enhancing decision-making - the need to identify and map knowledge related to the COVID-19 pandemic. There are no published studies appraising the critical knowledge areas for managing the spread of COVID-19 and for enhancing decision-making to tackle various facets of the pandemic. Therefore, this study aims to fill this gap.

The aim of this study is the appraisal of critical knowledge areas for managing COVID-19, and for enhancing decision-making to tackle the wide-ranging facets of the pandemic. Henceforth, the research question addressed is: "what are the critical knowledge areas for enhancing decision-making during the COVID-19 pandemic?". This study, thus, opens up a discussion about the new paradigm of emergent knowledge mapping strategies for public health emergencies. This study provides practical insights for professionals and decision-makers in helping them to identify the critical knowledge areas for addressing the COVID-19 pandemic.

This study involved a review of the literature to explore the critical knowledge areas for managing the COVID-19 pandemic and for facilitating decision-making in addressing its consequences. The study revealed seven critical knowledge areas for managing the COVID19 pandemic. They are: cleaning and disinfection; training, education and communication; reporting guidance and updates; testing; infection control measures, personal protective equipment; and potential COVID-19 transmission in health and other care settings. The study proposed a concept knowledge map illustrating these critical knowledge areas. This work makes a major contribution to research on $\mathrm{KM}$ and the management of public health 
emergencies by demonstrating how knowledge mapping, as one of the most powerful KM approaches, can enhance quick and effective decision-making.

The structure of the paper is as follows. It begins by presenting the theoretical background of $\mathrm{KM}$ and knowledge mapping, followed by a literature review of KM and knowledge mapping for COVID-19. Thereafter, the paper explains the research methodology adopted for this study. Analysis and discussion of the findings are then presented followed by conclusions and recommendations along with the implications for decision-makers and KM practitioners.

\section{Theoretical background}

\section{Knowledge management}

Bamel et al. (2021) noted that KM can be defined as an organisation's ability to "create, transfer, assemble, integrate and exploit knowledge assets". According to Gupta et al. (2000) $\mathrm{KM}$ can be defined as "a process that helps organizations find, select, organize, disseminate, and transfer important information and expertise necessary for activities such as problemsolving, dynamic learning, strategic planning, and decision- making". There is no single definition of KM as it has been conceptualised in a variety of ways; for example, it can be regarded as a management process, organisational ability or, as more recently, as a type of dynamic capability (Bamel and Bamel, 2018; Obeso et al., 2020; Bamel et al., 2021). However, the current literature on $\mathrm{KM}$ indicates that effective $\mathrm{KM}$ is related to the processes and infrastructures organisations use for knowledge acquisition, creation, generation, storage, sharing, dissemination and utilisation for formulating strategy, making strategic decisions and performance (Wang and Wu, 2020; Caputo et al., 2019; Ferreira et al., 2018; Malik et al., 2020; Zack, 2002) and that it is used to gain and sustain a competitive advantage (Davenport and Prusak, 1998; Ferreira et al., 2016; Heisig et al., 2016). In general, KM is considered to be a process that enables a firm "to leverage knowledge to enhance competitiveness" (Heisig et al., 2016).

A knowledge-based view of the firm states that these resources and capabilities are both knowledge-related and knowledge-intensive (Grant, 1996; Ferreira et al., 2018). According to Bamel et al. (2021), a knowledge-based view of a firm posits that firm-possessed knowledge is usually socially complex and difficult to imitate, thus leading to sustainable competitive advantage (Alavi and Leidner, 2001). According to Carayannis et al. (2017), effective KM requires functionality in three basic and essential organisational processes: the generation, dissemination and application of knowledge. In order to achieve this, organisations must maintain learning loops in all organisational processes; systematically disseminate new and existing knowledge throughout an organisation; and apply knowledge wherever it can be used in an organisation. Furthermore, the amount of information, knowledge, skills and other resources that companies can access and use has been identified as one of the key aspects of value co-creation (Caputo et al., 2019). Therefore, firm innovativeness and competitiveness may improve when alliances are established with partners who have strong capabilities and broad social capital, allowing them to create value, growth, technological knowledge and legitimacy through new knowledge resources (Vasudeva et al., 2013; Carayannis et al., 2017). Accordingly, Bamel et al. (2021) highlighted the importance of entering strategic alliances as a vital resource for the creation or acquisition of firm-specific knowledge. Through strategic alliances, firms can access to new knowledge, learn new things and thus, enhance their strategic position in a competitive landscape (Das and Kumar, 2007; Bamel et al., 2021). 
Papa et al. (2020) noted that innovating as well as transforming knowledge into economic value is the key to economic growth and competitive success in every business context. In this regard, a key aspect of the process of knowledge creation and innovation is the ability of the organisation to absorb external knowledge - absorptive capacity. This has emerged as a concept that connects across the literature on dynamic capabilities and organisational learning (Caputo et al., 2019). Papa et al. (2020) also noted that external knowledge sourcing is perceived not only as a key driver of business innovation performance but also as a crucial driver of growth for a technology-driven intelligent environment. According to Scuotto et al. (2017), absorptive capacity can be defined as an enterprise's ability to acquire external knowledge, combine and assimilate it within the organisational setting. Thus, it refers to an organisation's ability to convert external knowledge into innovation (Scuotto et al., 2017). Similarly, Mehreen et al. (2021) defined absorptive capacity as the ability of organisations, and the individuals within them, to understand and apply the information they receive. Additionally, Santoro et al. (2020) defined absorptive capacity as the ability to scan the external environment and to integrate new external knowledge into innovation processes. Singh et al. (2020) noted that absorptive capacity conveys an organisation's ability to advance its understanding, valuation, absorption and application of external knowledge by integrating particular activities to achieve competitive advantage and superior performance.

Scuotto et al. (2017) asserted that enterprises need to intensify their capacity to absorb external knowledge, mainly from the virtual environment, and combine it with internal knowledge. The authors further noted that absorptive capacity enables enterprises to convert external knowledge into new technological knowledge, thereby improving the knowledge capacity of enterprises and their innovation performance. Santoro et al. (2020) noted that absorptive capacity advances the ability of organisations to mix external knowledge with internal technical resources, and thus enhances their competitiveness. Singh et al. (2020) suggested that absorptive capacity represents a bridge between the external environmental factors affecting a firm and innovation-related activities which create value for enhanced performance. Thus, absorptive capacity enables firms to increase their stockpile of knowledge and to exploit external knowledge, and these capacities, in turn, improve innovation performance (Santoro et al., 2020). However, Singh et al. (2020) also noted that absorptive capacity is not simply developed in order to enhance a firm's innovation capability. Absorptive capacity enables the firm to adjust and develop its abilities by reconfiguring strategic resources to achieve present and future needs and enact appropriate responses to changes in the business environment.

The literature identified two categories of absorptive capacity (Cohen and Levinthal 1990; Lane and Lubatkin 1998; Scuotto et al., 2017): potential absorptive capacity and realised absorptive capacity. Potential absorptive capacity is characterised by knowledge acquisition and assimilation. Realised absorptive capacity is distinguished instead by knowledge transformation and exploitation. Moreover, Mehreen et al. (2021) noted various (internal and external) barriers to absorptive capacity. These barriers include, for example, weak social integration mechanisms, conflicting source relationships and poor appropriability regimes. The authors highlighted the impact of these barriers on limiting organisations' absorptive capacity and, in turn, on enhancing their competitive advantage.

The literature on KM has long suggested that knowledge sharing enables organisations to develop competitive advantage and enhances the capacity of employees to come up with creative solutions (Monteiro et al., 2008; Carayannis et al., 2017; Lee et al., 2021). Thus, organisations should be receptive to the development of new partnerships and adaptive to 
environmental changes, especially those arising from technological evolution (Caputo et al., 2019). Moreover, Iandolo et al. (2020) observed that, as a consequence of changing dynamics in social and business configurations, organisations which are interested in surviving over the time must develop frameworks which allow them, conceptually and operationally, to integrate smart technologies into KM processes in order to support decision-making and organisational value creation activities. For example, digital technology offers opportunities for creating experiences, processes and organisational forms that reshape organisations. Hence, it facilitates the accumulation of both internal and environmental change information, while exploiting insights that emerge as a result of the transformation of data into knowledge with strategic value. Such knowledge integrates the technology variable into the productive and business system, allowing proper cooperation and allowing advance decision-making processes to be established - especially those connected with the development of innovative processes (Castellanos and Torres, 2010; Carayannis et al., 2017).

The significance of information and communication technologies (ICTs) in every organisational process and, specifically, in the development and implementation of successful KM strategies has been highlighted in the literature (Caputo et al., 2019; Del Giudice et al., 2014; Zammuto et al., 2007; Becerra-Fernandez and Sabherwal, 2006; Malhotra, 2005). For instance, ICTs increase the speed and efficiency of information flows; this, in turn, facilitates the sharing and growth of knowledge (Kebede, 2010). Moreover, Seufert et al. (1999) noted that ICTs support interconnected knowledge networks but that they can, additionally, support relevant dimensions of KM processes such as storage, transfer, learning and measurement (Alavi and Leidner, 2001; Carayannis et al., 2017). Consequently, Wang and Wu (2020) noted that information technology (IT) plays a crucial role in the area of KM and can serve as a facilitator, thereby helping organisations achieve their goals.

Moreover, Carayannis et al. (2017) argued that big data are transforming the objects of knowledge by reformulating the most important questions regarding its very creation, from research to processing, and the characteristics of reality, raising awareness of how human networks and communities are developing. Papa et al. (2020) observed that "big" not only refers to the sheer volume of data but also their complexity and diversity. In accordance, the literature indicates that big data and big data analytics have been used to describe data sets and analytical techniques in applications so large and complex that they require advanced and unique data (Chen et al., 2012; Carayannis et al., 2017; Wang, 2012; Papa et al., 2020). The three most important characteristics of big data phenomena are the three "Vs": variety, velocity and volume. Their sheer scale necessitates a complete perspective shift compared to the approach required by traditional data analysis (Carayannis et al., 2017). Big data management creates or extracts knowledge from data and converts it into business advantage (McAfee and Brynjolfsson, 2012). Carayannis et al. (2017) observed that effective management of this knowledge leads to improved decision-making, which, in turn, increases organisational performance. Additionally, big data analytics generate improved solutions to complex organisational challenges, including the marketplace, supply chain navigation and societal and ecological performance. Therefore, organisations aiming to solve business problems and improve performance should systematically follow a process of well-defined stages to routinise the acquisition, assessment an activation of valuable knowledge from data at an accelerated rate (Chen et al., 2012; Wang, 2012; Carayannis et al., 2017).

Chaudhuri et al. (2020) noted that the ability to learn faster and adapt even more quickly provides corporations with the necessary core competence to acquire sustainable competitive advantage in a rapidly changing world order. Moreover, Singh et al. (2020) observed that 
innovation and strategic flexibility are two of the most important ways in which an organisation can achieve a competitive advantage over rivals in dynamic markets. Therefore, within the context of managing the COVID-19 pandemic, Iandolo et al. (2020) noted that, in addition to focusing on traditional public health outbreak response tactics (e.g., isolation, quarantining, social distancing, and community containment), other approaches based on sophisticated computational methods must be adopted.

Wang and $\mathrm{Wu}(2020)$ noted that, in order to make appropriate strategic decisions, it is necessary to acquire critical knowledge rapidly; therefore, it is crucial to develop a specific set of KM procedures to deal with the COVID-19 outbreak. Kruesi et al. (2020) noted that the management of biomedical knowledge is key to achieving satisfactory levels of health care. In this regard, Iandolo et al. (2020) highlighted the importance of highlighting the role of data and knowledge sharing in times of outbreak and disaster in order to support global understanding and efficient decision-making processes (Allam and Jones 2020; Iandolo et al., 2020; Wang and $\mathrm{Wu}, 2020$ ). Additionally, Lee et al. (2021) noted that employees' active knowledge sharing is even more critical in a crisis as it helps to identify and solve problems quickly and effectively. Knowledge sharing is particularly important in the context of the crisis because the exchange of information, ideas and suggestions allows employees to identify or create actionable problem-solving knowledge and practice, resulting in clear orientation and guidance to deal with complex tasks and environments during the crisis (Lee et al., 2021). Papa et al. (2020) noted that the application of smart technologies within the e-Health-care industry promotes knowledge flows among stakeholders opening up promising new threads of knowledge, which can transform the basis of technological innovation and corporate competition.

Therefore, it is necessary to build strategies to ensure open knowledge sharing among employees during a crisis such as the COVID-19 outbreak. Smart technologies assisted in containing the spread of the virus by enabling the acquisition of data from hundreds of millions of smartphones. As a result, authorities were able to increase their efficiency in terms of the use of limited medical resources. For instance, AI has been used to identify and test for the virus in high-risk subjects (Iandolo et al., 2020). Moreover, Lee et al. (2021) noted that employees' active knowledge-sharing behaviour and knowledge maps have great potential to help organisations make quick and effective decisions and be resilient in a crisis, such as during the current COVID-19 pandemic.

\section{Knowledge mapping}

In recent years, awareness has grown about the strategic importance of knowledge within an organisation in terms of its strategic value linked to knowledge and the exploitation of knowledge (Brahami et al., 2013). Originally developed for and applied in business management, knowledge mapping was proposed as a technique to foster knowledge management in organisational contexts to increased innovation and performance (Vimal and Morgans, 2020). It helps to describe what, how and where to find useful knowledge within an organisation. Knowledge can be mapped in order that it can be acquired, monitored, created, shared, and finally capitalised on and transferred (Brahami et al., 2013). Thus, knowledge mapping aims to mobilise, diffuse and evaluate intellectual capital in a given organisation (Wexler, 2001). Moreover, knowledge mapping helps to identify necessary skills and information, encourages the reuse of ideas, prevents reinvention, highlights islands of expertise and emerging practices (Liebowitz et al., 2000). The map can, for instance, reveal who holds 
what type of knowledge, how it is stored and maintained, and what media are used to disseminate and transfer it (Burnett et al., 2004; Vimal and Morgans, 2020).

Balaid et al. (2016) noted that there can be several objectives when utilising knowledge maps. Some organisations view it as an activity that can help them with strategic planning, while others may use it as a basis for knowledge transfer. In general, knowledge mapping deals with the problem of how best to visualise knowledge assets in order to perform specific activities, particularly when organisations that value knowledge are eager to recognise how, when and where to access it (Wexler, 2001; Balaid et al., 2016).

According to Brahami et al. (2013) knowledge mapping is a means of (cognitive) navigation to access the strategic heritage knowledge resources of an organisation. The authors noted that there are numerous definitions of knowledge maps in the literature. Although the concept has been defined in various ways from different viewpoints, there have been no universal definitions of knowledge maps so far. While research on knowledge maps is still in its infancy, over the past few years the number of studies researching the phenomenon has continuously been increasing. There are now several streams of research central to knowledge maps, such as network analysis, information visualisation and text mining (Balaid et al., 2016); however, according to Davenport and Prusak (1998), a knowledge map - whether it is an actual map, knowledge "yellow pages" or a cleverly constructed database - points to knowledge but does not contain knowledge. A knowledge map is a guide not a repository.

On the other hand, despite the inherent value of mapping organisational knowledge, certain barriers may impede the effectiveness of the technique (APQC, 2018b). For example, the American Productivity and Quality Center (APQC) (2018b) noted that one of the main barriers encountered in knowledge mapping occurs when the team doing the mapping does not understand the knowledge flow process inside the organisation. Therefore, it is important to ensure that organisations have commonly accepted and widely used validation processes in order to maintain the validity of expertise or content of the knowledge map. The so-called "knowledge is power" syndrome that exists in many organisations is another key barrier for effective knowledge mapping (APQC, 2018b). Therefore, organisations must encourage and promote a knowledge-sharing culture to win over reluctant employees who feel threatened that their own positions as employees may be compromised by sharing (Abdalla et al., 2020).

Stirling and Scoones (2009) noted that governance of infectious disease risks (e.g., COVID19) requires an understanding of often indeterminate interactions between diverse, complex, open, and dynamic human and natural systems. Furthermore, the findings of Cargnel et al. (2021) revealed the usefulness of knowledge mapping as a tool for visualising and identifying gaps and ultimately gaining insight into alternatives for better preparedness and responsiveness in different epidemiological scenarios. Therefore, mapping and sharing knowledge on public health emergencies, such as COVID-19, could allow key knowledge to be rapidly identified and could connect various users and stakeholders at various levels, e.g., national, regional and international levels. In this context, technical support could be provided, experiences could be shared and multilateral cooperation could be established or strengthened.

\section{COVID-19 and knowledge management}

It is considered to be one of the instruments which can help organisations adapt during times of rapid change when policies and protocols are developing quickly, and uncertainty is constantly present (Buheji and Buhaid, 2020). Wang and Wu (2020) noted that, in the case of 
an epidemic prevention plan, the first critical KM task is to identify what knowledge is required. Both tacit and explicit knowledge related to the COVID-19 pandemic need to be retrieved and transferred carefully. There is a significant amount of similar professional expertise that is difficult to explicate and may be labelled as tacit (Buheji and Buhaid, 2020; Wang and $\mathrm{Wu}, 2020)$. In fact, tacit knowledge, as defined by Polanyi (1966), is potentially more important for professionals than explicit knowledge. Tacit knowledge involves knowledge that cannot necessarily be explicated but can be employed in practical situations. It is described as "know-how" as opposed to "know-that" and constitutes an important characteristic of expertise (Polanyi, 1966).

Hossain (2020) concluded that to solve problems and global emergencies like COVID-19, it is necessary to fully understand the problem and possible solutions. This highlights the need for knowledge as a fundamental force that keeps science alive and allows scientists to thrive in their research domains supported by the best possible methods and materials to answer reallife questions. Managing COVID-19-related knowledge can help reduce the transmission of the disease and promote readiness while maintaining a safe environment (Buheji and Buhaid, 2020). Wang and $\mathrm{Wu}$ (2020) observed that establishing and deploying a dedicated KM platform to collect and manage the most up-to-date knowledge is essential. The authors argued that the utilisation of such platforms can enhance the accuracy, integrity and reliability of the knowledge acquired, which can mitigate panic and fear caused by misinformation and allow critical knowledge to be fully disseminated, evaluated and continuously refined when necessary. Managing COVID-19-related knowledge requires suitable organisational infrastructure which includes all technical information systems capable of collecting, storing, processing and analysing different kinds of data; this is fundamental to facilitating the flow of data in any situation (Wamba et al., 2017). Buheji and Buhaid (2020) concluded that there are four sources of knowledge that come from monitoring, anticipating, responding, and learning. These sources enhance the ability of systems to succeed under varying conditions. The authors also noted that the dramatic rise of the number of people infected with COVID-19 combined with staff shortages in intensive care competencies calls for innovative solutions. This highlights the need to capture and share knowledge to help to improve the process of care at every opportunity and to reduce patient safety risks (Buheji and Buhaid, 2020).

Chellamuthu and Muthu (2020) argued that an integrated pragmatic approach under the WHO is essential in containing pandemics as international cooperation is required at various levels; these range from knowledge sharing to monetary support. Meanwhile, Nathavitharana et al. (2020) remarked that data characterising the extent of occupational infections in healthcare workers (HCWs) during acute and chronic epidemics are often lacking and subject to wide variability in reporting, which limits their impact. For example, HCWs in countries with high tuberculosis (TB) incidence have at least twice the risk of developing TB, compared with the general population. Although there are still major gaps in national data collection regarding the incidence of occupational TB, recent attempts by the WHO to systematically record this data have resulted in increasing prioritisation of this group as an at-risk population who may benefit from TB preventive therapy (Elavarasan and Pugazhendhi, 2020; Vaishya et al., 2020). Therefore, Nathavitharana et al. (2020) strongly advocate for health systems to systematically record and share longitudinal data on numbers of HCWs infected with COVID-19. This transparency will facilitate urgent action to replenish and sustain resources such as personal protective equipment (PPE) and enable institutions to share and adopt successful infection prevention strategies. Examples such as the prevention of central line-associated bloodstream infections demonstrate the potential impact of national collaborative efforts to strengthen 
infection prevention, although further effort is needed to optimise knowledge sharing in the context of outbreaks (Nathavitharana et al., 2020).

On the other hand, Zhou et al. (2020c) noted the impact of the spread of low credibility information regarding COVID-19. According to the authors, along with the COVID-19 pandemic, we are also experiencing an "infodemic" of information with low credibility regarding COVID-19. Hundreds of news websites have contributed to publishing false coronavirus information. Individuals who believe false news articles (e.g., claiming that eating boiled garlic or drinking chlorine dioxide can cure or prevent coronavirus) might try ineffective or extremely dangerous actions to protect themselves from the virus (Zhou et al., 2020c). Nevertheless, the more knowledge that is accumulated without proper sharing at the right time, the more difficult it becomes to communicate. Thus, Heldal et al. (2019) suggest that knowledge development hinges on the ability to translate between tacit and explicit knowledge (Nonaka and Takeuchi, 1995). Table 1 highlights the literature related to COVID-19 and KM which has been reviewed in this study. 
Table 1: The analysis of the reviewed literature related to COVID-19 and managing knowledge

\begin{tabular}{|c|c|c|c|c|c|}
\hline Reference & Title & Source & $\begin{array}{l}\text { Country/ } \\
\text { Territory }\end{array}$ & Methods & Discussion \\
\hline $\begin{array}{l}\text { Al Hakim et } \\
\text { al. }(2020)\end{array}$ & $\begin{array}{l}\text { An empirical study of knowledge } \\
\text { mapping implementation in Indonesian } \\
\text { organisational context. }\end{array}$ & $\begin{array}{l}\text { VINE Journal of } \\
\text { Information and } \\
\text { Knowledge } \\
\text { Management } \\
\text { Systems. }\end{array}$ & Indonesia & $\begin{array}{l}\text { Questionnaire/ } \\
\text { survey }\end{array}$ & $\begin{array}{l}\text { Indicates that the support of technology through the use of AI, it is } \\
\text { expected to be able to present a comprehensive, adaptive and } \\
\text { objective knowledge mapping for the organisation. }\end{array}$ \\
\hline $\begin{array}{l}\text { Al-Hity et al. } \\
(2021)\end{array}$ & $\begin{array}{l}\text { Personal protective equipment } \\
\text { guidance during a global pandemic: A } \\
\text { statistical analysis of National } \\
\text { perceived confidence, knowledge and } \\
\text { educational deficits amongst UK-based } \\
\text { doctors. }\end{array}$ & $\begin{array}{l}\text { International } \\
\text { Journal of } \\
\text { Clinical Practice, }\end{array}$ & UK & Survey & $\begin{array}{l}\text { Highlights the need for more education and for a paradigm shift } \\
\text { towards increased use of video-streaming and virtual media to } \\
\text { exchange knowledge and facilitate learning. }\end{array}$ \\
\hline $\begin{array}{l}\text { Anttiroiko } \\
(2021)\end{array}$ & $\begin{array}{l}\text { Successful government responses to } \\
\text { the pandemic: Contextualising national } \\
\text { and urban responses to the COVID-19 } \\
\text { outbreak in east and west. }\end{array}$ & $\begin{array}{l}\text { International } \\
\text { Journal of E- } \\
\text { Planning } \\
\text { Research }\end{array}$ & Finland & $\begin{array}{l}\text { Descriptive } \\
\text { multiple case } \\
\text { study }\end{array}$ & $\begin{array}{l}\text { Discusses national and local strategies for confronting the } \\
\text { COVID-19 pandemic. Also, sheds light on how knowledge and } \\
\text { other societal and institutional arrangements in addition to } \\
\text { technology deployment manifest in national responses to the } \\
\text { pandemic. }\end{array}$ \\
\hline $\begin{array}{l}\text { Bhamra et } \\
\text { al.,(2021) }\end{array}$ & $\begin{array}{l}\text { Personal protective equipment: } \\
\text { knowledge of the guidance. }\end{array}$ & $\begin{array}{l}\text { British Journal of } \\
\text { Nursing }\end{array}$ & Undefined & Survey & $\begin{array}{l}\text { Concluded that unifying published PPE guidance and ensuring } \\
\text { consistency in training can improve awareness, confidence and } \\
\text { knowledge among nursing staff. }\end{array}$ \\
\hline $\begin{array}{l}\text { Buheji and } \\
\text { Buhaid (2020) }\end{array}$ & $\begin{array}{l}\text { Capturing Accumulated Knowledge } \\
\text { and Learning of COVID-19 Pandemic } \\
\text { from Front-Line Nurse. }\end{array}$ & $\begin{array}{l}\text { Human Resource } \\
\text { Management } \\
\text { Research }\end{array}$ & Bahrain & $\begin{array}{l}\text { Literature } \\
\text { review }\end{array}$ & $\begin{array}{l}\text { Investigates the type of nurses' COVID-19 knowledge } \\
\text { accumulated and then suggests through a framework a way of } \\
\text { dealing with it. }\end{array}$ \\
\hline Casella (2021) & $\begin{array}{l}\text { Can the COVID- } 19 \text { epidemic be } \\
\text { controlled on the basis of daily test } \\
\text { reports? }\end{array}$ & $\begin{array}{l}\text { IEEE Control } \\
\text { Systems Letters }\end{array}$ & Italy & Letter & $\begin{array}{l}\text { Examines how COVID-19 epidemics can be controlled by } \\
\text { authorities taking decisions on public health measures on the basis } \\
\text { of daily reports of swab test results, active cases and total cases. }\end{array}$ \\
\hline
\end{tabular}


AAM- Journal of Knowledge Management, DOI: 10.1108/JKM-01-2021-0083

Critical knowledge areas for managing the COVID-19 pandemic

\begin{tabular}{|c|c|c|c|c|c|}
\hline $\begin{array}{l}\text { Chellamuthu } \\
\text { and Muthu } \\
(2020)\end{array}$ & $\begin{array}{l}\text { Pandemic response protocol of a non- } \\
\text { frontline specialty in a multispecialty } \\
\text { tertiary health care centre-a pilot } \\
\text { model in orthopaedics. }\end{array}$ & $\begin{array}{l}\text { International } \\
\text { Orthopaedics }\end{array}$ & India & $\begin{array}{l}\text { Pilot model in } \\
\text { orthopaedics }\end{array}$ & $\begin{array}{l}\text { Suggests that an integrated pragmatic approach is essential in } \\
\text { containing pandemics as they need international cooperation at } \\
\text { various levels, starting from knowledge sharing to monetary } \\
\text { support. }\end{array}$ \\
\hline $\begin{array}{l}\text { Elavarasan and } \\
\text { Pugazhendhi } \\
(2020)\end{array}$ & $\begin{array}{l}\text { Restructured society and environment: } \\
\text { A review on potential technological } \\
\text { strategies to control the COVID-19 } \\
\text { pandemic. }\end{array}$ & $\begin{array}{l}\text { Science of The } \\
\text { Total } \\
\text { Environment }\end{array}$ & India & $\begin{array}{l}\text { Literature } \\
\text { survey }\end{array}$ & $\begin{array}{l}\text { Investigates various technology-based strategies that assist the } \\
\text { environment in controlling the pandemic and also other viable } \\
\text { technologies that have the potential to be used. }\end{array}$ \\
\hline $\begin{array}{l}\text { Holmgren et } \\
\text { al. }(2020)\end{array}$ & $\begin{array}{l}\text { Barriers to hospital electronic public } \\
\text { health reporting and implications for } \\
\text { the COVID-19 pandemic. }\end{array}$ & $\begin{array}{l}\text { Journal of the } \\
\text { American } \\
\text { Medical } \\
\text { Informatics } \\
\text { Association }\end{array}$ & USA & $\begin{array}{l}\text { Combined } \\
\text { survey and } \\
\text { hospital reports } \\
\text { data }\end{array}$ & $\begin{array}{l}\text { Suggests that public health agencies' inability to receive electronic } \\
\text { data is the most prominent hospital-reported barrier to effective } \\
\text { syndromic surveillance. }\end{array}$ \\
\hline $\begin{array}{l}\text { Islam et al. } \\
(2020)\end{array}$ & $\begin{array}{l}\text { Current knowledge of COVID-19 and } \\
\text { infection prevention and control } \\
\text { strategies in healthcare settings: A } \\
\text { global analysis. }\end{array}$ & $\begin{array}{l}\text { Infection Control } \\
\& \text { Hospital } \\
\text { Epidemiology }\end{array}$ & Australia & $\begin{array}{l}\text { Literature } \\
\text { review }\end{array}$ & $\begin{array}{l}\text { Infection prevention and control strategies should consider all the } \\
\text { possible routes of transmission and should target all patient care } \\
\text { activities involving risk of person-to-person transmission. }\end{array}$ \\
\hline $\begin{array}{l}\text { La Marca et al. } \\
(2020)\end{array}$ & $\begin{array}{l}\text { Testing for SARS-CoV-2 (COVID-19): } \\
\text { a systematic review and clinical guide } \\
\text { to molecular and serological in-vitro } \\
\text { diagnostic assays. }\end{array}$ & $\begin{array}{l}\text { Reproductive } \\
\text { biomedicine } \\
\text { online }\end{array}$ & Italy & $\begin{array}{l}\text { Literature } \\
\text { review }\end{array}$ & $\begin{array}{l}\text { Highlights the importance of the different testing approaches for } \\
\text { SARS-Cov-2 in the fight against this pandemic. }\end{array}$ \\
\hline $\begin{array}{l}\text { Nathavitharana } \\
\text { et al. (2020) }\end{array}$ & $\begin{array}{l}\text { Innovation and Knowledge Sharing } \\
\text { Can Transform COVID-19 Infection } \\
\text { Prevention Response. }\end{array}$ & $\begin{array}{l}\text { Journal of } \\
\text { hospital medicine }\end{array}$ & USA & $\begin{array}{l}\text { Literature } \\
\text { review }\end{array}$ & $\begin{array}{l}\text { Focuses on the potential for innovation and knowledge sharing } \\
\text { from an infection prevention perspective, which could enhance } \\
\text { frontline HCW safety in the current COVID-19 pandemic. }\end{array}$ \\
\hline $\begin{array}{l}\text { Parra et al. } \\
(2021)\end{array}$ & $\begin{array}{l}\text { Information and communication } \\
\text { technologies (ICT)-enabled severe } \\
\text { moral communities and how the } \\
\text { (Covid19) pandemic might bring new } \\
\text { ones. }\end{array}$ & $\begin{array}{l}\text { International } \\
\text { Journal of } \\
\text { Information } \\
\text { Management }\end{array}$ & Norway & $\begin{array}{l}\text { Analytical } \\
\text { framework }\end{array}$ & $\begin{array}{l}\text { Discusses how ICTs may enable the emergence of severe moral } \\
\text { communities, and help to promote increasingly polarised, } \\
\text { radicalised and even extremist viewpoints. }\end{array}$ \\
\hline $\begin{array}{l}\text { Rowan and } \\
\text { Laffey (2020) }\end{array}$ & $\begin{array}{l}\text { Challenges and solutions for } \\
\text { addressing critical shortage of supply } \\
\text { chain for personal and protective } \\
\text { equipment (PPE) arising from } \\
\text { Coronavirus disease (COVID19) } \\
\text { pandemic-Case study from the } \\
\text { Republic of Ireland. }\end{array}$ & $\begin{array}{l}\text { Science of The } \\
\text { Total } \\
\text { Environment }\end{array}$ & Ireland & Case study & $\begin{array}{l}\text { Logical first step solutions for PPE shortages would be to improve } \\
\text { communication lines for better stock management that exploits } \\
\text { webpage and mobile phone app development. }\end{array}$ \\
\hline
\end{tabular}


AAM- Journal of Knowledge Management, DOI: 10.1108/JKM-01-2021-0083

Critical knowledge areas for managing the COVID-19 pandemic

\begin{tabular}{|c|c|c|c|c|c|}
\hline $\begin{array}{l}\text { Swanson and } \\
\text { Santamaria } \\
(2021)\end{array}$ & $\begin{array}{l}\text { Pandemic Supply Chain Research: A } \\
\text { Structured Literature Review and } \\
\text { Bibliometric Network Analysis. }\end{array}$ & Logistics & USA & $\begin{array}{l}\text { A Structured } \\
\text { Literature } \\
\text { Review and } \\
\text { Bibliometric } \\
\text { Network } \\
\text { Analysis. } \\
\end{array}$ & $\begin{array}{l}\text { Addresses, summarises and articulates supply chain management } \\
\text { issues during pandemics by focusing primarily on the bulk of the } \\
\text { research that has been published since the COVID-19 pandemic } \\
\text { began. }\end{array}$ \\
\hline $\begin{array}{l}\text { Vaishya et al. } \\
(2020)\end{array}$ & $\begin{array}{l}\text { Artificial Intelligence (AI) applications } \\
\text { for COVID-19 pandemic. }\end{array}$ & $\begin{array}{l}\text { Diabetes \& } \\
\text { Metabolic } \\
\text { Syndrome: } \\
\text { Clinical Research } \\
\text { \& Reviews. }\end{array}$ & India & $\begin{array}{l}\text { Literature } \\
\text { review }\end{array}$ & $\begin{array}{l}\text { Concludes that healthcare organisations are in an urgent need for } \\
\text { decision-making technologies to handle COVID-19 and help them } \\
\text { in getting proper suggestions in real-time to avoid its spread. AI } \\
\text { works in a proficient way to mimic like human intelligence. }\end{array}$ \\
\hline $\begin{array}{l}\text { Wu et al. } \\
(2020 \mathrm{a})\end{array}$ & $\begin{array}{l}\text { Environmental contamination by } \\
\text { SARS-CoV-2 in a designated hospital } \\
\text { for coronavirus disease } 2019 \text {. }\end{array}$ & $\begin{array}{l}\text { American journal } \\
\text { of infection } \\
\text { control }\end{array}$ & China & $\begin{array}{l}\text { Air and surface } \\
\text { SARS-CoV-2 } \\
\text { RNA detection. }\end{array}$ & $\begin{array}{l}\text { Investigates whether environmental contamination may play a role } \\
\text { in SARS-CoV-2 transmission. }\end{array}$ \\
\hline $\begin{array}{l}\text { Yang et al. } \\
(2020)\end{array}$ & $\begin{array}{l}\text { Knowledge system analysis on } \\
\text { emergency management of public } \\
\text { health emergencies. }\end{array}$ & Sustainability & China & $\begin{array}{l}\text { Literature } \\
\text { review }\end{array}$ & $\begin{array}{l}\text { Addresses the challenge of building a knowledge system for } \\
\text { emergency management of public health emergencies. }\end{array}$ \\
\hline $\begin{array}{l}\text { Younan et al. } \\
(2020)\end{array}$ & $\begin{array}{l}\text { Challenges and recommended } \\
\text { technologies for the industrial internet } \\
\text { of things: A comprehensive review. }\end{array}$ & Measurement & Egypt & $\begin{array}{l}\text { Comprehensive } \\
\text { review }\end{array}$ & $\begin{array}{l}\text { Suggests that enabling real-time data analysis, knowledge } \\
\text { extraction and search techniques based on ICT (e.g., ML, AI) can } \\
\text { reduce and control IoT and leverage its value. }\end{array}$ \\
\hline $\begin{array}{l}\text { Zhou et al. } \\
(2020 \mathrm{a})\end{array}$ & Challenges to GIS with big data. & $\begin{array}{l}\text { Geography and } \\
\text { Sustainability }\end{array}$ & China & $\begin{array}{l}\text { Data-driven } \\
\text { multi-scale } \\
\text { mapping }\end{array}$ & $\begin{array}{l}\text { Provides analysis of the spatial representation of COVID-19 } \\
\text { material, population and social psychology at individual, group } \\
\text { and regional levels. }\end{array}$ \\
\hline $\begin{array}{l}\text { Zhou et al. } \\
\text { (2020b) }\end{array}$ & $\begin{array}{l}\text { Investigating SARS-CoV-2 surface and } \\
\text { air contamination in an acute healthcare } \\
\text { setting during the peak of the COVID- } \\
19 \text { pandemic in London. }\end{array}$ & $\begin{array}{l}\text { Clinical } \\
\text { Infectious } \\
\text { Diseases. }\end{array}$ & UK & $\begin{array}{l}\text { Cross-sectional } \\
\text { observational } \\
\text { study }\end{array}$ & $\begin{array}{l}\text { Evaluates SARS-CoV-2 surface and air contamination during the } \\
\text { COVID-19 pandemic and reveals that surface contamination was } \\
\text { detected on a range of items. }\end{array}$ \\
\hline
\end{tabular}




\section{COVID-19 and knowledge mapping}

Arshad et al. (2021) noted that the recent COVID-19 pandemic, probably of zoonotic origin, necessitates appraisal of a multi-disciplinary "One Health" approach by coordinating human, animal and environment professionals. Community health is a complex multi-factorial process, and many components are covered under the umbrella of One Health. The One Health core competencies (collaboration, coordination, partnership, leadership, communication, ethics, systems thinking and management) have been identified as being significant in responding to pandemics or public health issues globally. Examples include the Bellagio working group, USAID/RESPOND, SMM, Rome Synthesis, and PREDICT (Frankson et al., 2016; Andersen et al., 2020; Zhou et al., 2020a). Despite the high surge in the volume of scientific interest in pandemic response, ranging from proposals for innovative medical devices, vaccines and infection prediction to propagation models for COVID-19 (e.g., specific search and recommendation tools developed for COVID-19), systems that leverage graph-based interactive visualisations to navigate the vast research materials are not yet available (Ambavi et al., 2020).

Casella (2021) noted that governments all the world over are having to make very challenging life-or-death decisions regarding the management of the COVID-19 epidemic; these involve a balance between public health and economic issues. To take such decisions, they rely on expert advice based on the results of epidemiological mathematical models and on daily case reports, based on swab test results. Furthermore, Moreira et al. (2019) noted that healthcare experts make several decisions every day. These can have important effects on their patients' health and their wellbeing. Although medical care is improving, the escalating amount of data and, consequently, the way in which those data can relate to patients, are making these decisions more and more complicated (Moreira et al., 2019). Therefore, sharing critical knowledge in order to manage COVID-19 is necessary to facilitate and enhance decision-making. For instance, Goniewicz et al. (2020) noted that national authorities should share best practices and seek a consensus on common approaches with the assistance of WHO.

Sturm et al. (2017) discuss how one way of addressing the needs of KM is through knowledge mapping. The authors highlighted how knowledge maps increase knowledge visibility and transparency, helping to place knowledge in a wider context and support effective communication. Moradi et al. (2017) noted that utilising a knowledge map greatly facilitates any individual's or group's decision-making process, by proposing or establishing key information which is necessary for an informed response. This process is, thus, the initial basis and one of the keys to success in the application of KM in organisations. Daňa et al. (2020) noted that specific interaction patterns are related to increased knowledge flow, innovativeness and performance.

According to Mital et al. (2018), the knowledge used by decision makers is tacit knowledge, and they generally use certain mental models for evaluation when making a decision. Al Hakim et al. (2020) noted that knowledge mapping is an essential part of KM, stating that a knowledge map can be a bridge when implementing the KM system (KMS). A knowledge map does not contain knowledge, but, rather, it includes a conceptual picture of knowledge that demonstrates the relationships between different aspects of knowledge (knowledge profile), locations (link to the site) and knowledge owners (expert) (Kim et al., 2003). Therefore, knowledge mapping represents a great opportunity to enhance skills and competencies and to improve and facilitate decision-making. Thus, it is essential to develop dynamic knowledge mapping platforms to 
help to connect key stakeholders to existing explicit (codified) and tacit (practical) knowledge and facilitate knowledge exchange (Buheji and Buhaid, 2020).

Moreover, since the outbreak of COVID-19, in addition to policy documents published by governments, epidemic information has been widely disseminated through various online platforms and channels. However, as COVID-19-related data and information originates from various sources, it is unstructured, inconsistent and inaccurate (Zhou et al., 2020a). Managing COVID-19-related knowledge necessitates the effective collection, storage, retrieval, mining and sharing of data (Younan et al., 2020). There are huge challenges when accessing and aggregating such a vast amount of information and knowledge (Nguyen et al., 2020). Hence, answering real-time queries can become extremely challenging (Younan et al., 2020). Moreira et al. (2019) noted that, nowadays, people can use information and communication technologies to facilitate the interaction between patients and their physicians, improving the patient's quality of life. Physicians can have easy access to patients' medical records, lab results, images and information about their medication, anytime and anywhere. In the same way, patients can have access to information on their diagnostic situation as well as information about how to be as healthy as possible (Moreira et al., 2019).

According to Zhou et al. (2020a), convenient multi-scale dynamic mapping for epidemics is one of the key challenges associated with using geographic information system (GIS) with spatiotemporal big data in order to manage the COVID-19 pandemic. The challenge when knowledge mapping is to understand how to create practical solutions to support individuals and groups as they generate or acquire this multi-faceted knowledge in a way which suits the particular requirements of their application context (Storey and Barnett, 2000; Suresh and Egbu, 2008). When done well, KM can be used as a tool to evaluate the corporate knowledge stock (e.g., knowledge of COVID-19) revealing strengths to be exploited and gaps that need to be filled (Davenport and Prusak, 1998). In order to manage the COVID-19 pandemic and control the spread of the virus, organisations need to grow the capability to share knowledge between specialised areas and across internal and external boundaries. Therefore, identifying the sets of knowledge that will make the greatest difference, where they reside and how they can be accessed and exploited for team, organisational and communal benefits is fundamental. This consideration is integral to the issue of knowledge mapping.

Wexler (2001) noted that the benefits of a knowledge map can be categorised into four groups of returns: knowledge, economic, structural and organisational/cultural. Moreover, Yasin and Egbu (2011) categorised the benefits of a knowledge map into five themes: cost saving, process improvements, knowledge improvement, value improvement and user satisfaction. However, the clearest benefit and the principal purpose of a knowledge map is to show people in an organisation where to go and who to ask when they need expertise (Wexler, 2001; Balaid et al., 2016). Therefore, a knowledge map can increase transparency and reduce complexity within organisational contexts as well as preventing overlapping and repetitive activities (Wexler, 2001; Yasin and Egbu, 2011).

The American Productivity and Quality Center (APQC) (2018b) stated that the key benefits of knowledge mapping include: bringing stakeholders together to think critically about the knowledge involved in their work; highlighting the areas where critical knowledge may be at risk; enabling opportunities to create value by facilitating comprehensive collaboration and knowledge sharing; and facilitating broader in-depth knowledge transfer. Additionally, knowledge mapping techniques are relatively easy to apply, even for teams with minimal 
experience. This is especially true when compared with improvement methodologies such as Six Sigma, which require significant participant training (APQC, 2018b).

\section{Research methodology}

\section{Developing the concept map}

This study sought to evaluate the critical knowledge areas for managing the COVID-19 outbreak. Knowledge mapping allows a fine-tuned understanding, by critically analysing the domains of knowledge to identify where efforts should be made in terms of capitalisation, sharing or innovation (Brahami et al., 2013). The study followed the APQC (2018a) four-step guide to knowledge mapping: identify knowledge areas; draft knowledge map; evaluate risks and identify opportunities; act on the map. Using data from global infection prevention and control (IPC) guidelines compiled by organisations such as the World Health Organization (WHO), Department of Health and Social Care (DHSC), Public Health England (PHE), and the Toolkit on State Actions to Mitigate COVID-19 Prevalence in Nursing Homes, the authors identified key knowledge areas for controlling the spread of COVID-19 and combined this information with the findings from the systematic literature review reported in Table 4. This approach allowed the most important critical knowledge areas to be pinpointed.

As mentioned above, the aim of this research is to appraise critical knowledge areas in order to manage the spread of COVID-19 and to enhance decision-making to tackle the consequences of the pandemic. In order to achieve this aim, a robust methodology was adopted. The study is based on a critical analysis of the extant literature devoted to knowledge mapping and COVID19 , and discusses the potential role of knowledge mapping techniques in managing and controlling the spread of the virus and in facilitating decision-making towards recovery. Finally, the paper proposes a concept map of the areas where knowledge mapping techniques can be adopted to facilitate containment and control of the virus efforts and tackle the consequences of the pandemic. A research literature review is a "systematic, explicit, and reproducible method for identifying, evaluating, and synthesising the existing body of completed and recorded work produced by researchers, scholars, and practitioners" (Castaneda et al., 2018). The critical literature review (CLR) approach entails the assessment, critique and synthetisation of relevant literature regarding the topic under investigation in a manner that creates a firm foundation for advancing knowledge and facilitating new theoretical frameworks and perspectives to emerge from a wide array of different fields (Snyder, 2019). Examples of this type of review are not new in business literature (Snyder, 2019). As such, adopting a critical literature review approach is favoured in realising the goal of the paper as it allows for the inclusion of a wide range of perspectives and theoretical underpinnings from different sources (Ibn-Mohammed et al., 2021).

The method used in this study followed that proposed by Tranfield et al. (2003), involving three stages (see Table 2): planning the review, conducting the review and reporting, and disseminating the results. The first stage involved developing a list of keywords and criteria for the inclusion of articles, as well as defining the search string to be input into the data source. Thereafter, two keywords, namely "knowledge mapping", and "COVID-19" were identified and combined. The resulting search string was ["COVID-19" OR "Coronavirus"] AND ["knowledge mapping" OR "knowledge map"] and this was used to search the titles, abstracts and keywords of available articles. A university library search engine, with access to various databases, including Directory of Open Access Journals, Science Direct, Scopus, TRID, Web of Science and Wiley Online Library, was used to complete an online search. 
Table 2: Stages of the literature review

\begin{tabular}{|ll|}
\hline Stage I - Planning the review & \\
\hline Phase 0 & Identify the need for the review \\
Phase 1 & Prepare a review protocol \\
Phase 2 & Develop criteria for inclusion \\
\hline Stage II - Conducting the review & \\
\hline Phase 3 & Carrying out the review of relevant articles \\
Phase 4 & Screening and applying inclusion criteria \\
Phase 5 & Assess study quality \\
Phase 6 & Extract and monitor data \\
Phase 7 & Data synthesise \\
\hline Stage III - Reporting and disseminating the results \\
\hline Phase 8 & Specify dissemination strategy \\
Phase 9 & Critically document and present the results \\
Phase 10 & Evaluate the report \\
\hline
\end{tabular}

Strict inclusion criteria were used to identify appropriate studies in order to provide the best quality evidence available (see Table 3 ). The inclusion criteria were that articles should be full text, peer-reviewed journal articles, available online, in English and published between December 2019 and January 2021 (to ensure relevance to COVID-19); additionally, they had to have relevance to the research aim. According to Natalicchio et al. (2017), such choices are justified by the fact that inclusion criteria ensure the identification of the most relevant articles related to the topic under investigation. The second stage involved carrying out a review of the relevant articles. The initial search identified a total of 75 articles. These records were then screened and reduced to 42 by applying the inclusion criteria. The articles were then "eyeballed" to ensure they were consistent with the keyword search, the abstracts were assessed against the research aim, and the duplicates removed. The total number of articles was reduced to 32 as a result of this process. The full text of the selected articles was read to determine the relevance with respect to the aim of the study and the results were narrowed down to 21 articles. Finally, these 21 articles were reviewed, categorised and analysed. The third and final stage involved reporting and dissemination. This stage involved critically documenting and presenting the results from the analysis of the selected articles. A discussion of the critical knowledge areas for managing COVID-19 is outlined in the next section.

Table 3: Criteria for inclusion/ exclusion of studies

\begin{tabular}{|l|l|l|}
\hline & Inclusion criteria & Exclusion criteria \\
\hline Date & December 2019 - May 2021 & Prior December 2019 \\
\hline Language & English & Papers not in English \\
\hline Type & Original research papers & $\begin{array}{l}\text { Articles and book reviews, } \\
\text { dissertations }\end{array}$ \\
\hline Publications & $\begin{array}{l}\text { Peer-reviewed articles, } \\
\text { government reports } \\
\text { Conference papers, book } \\
\text { chapters, books, conference } \\
\text { papers, and unpublished } \\
\text { works. }\end{array}$ \\
\hline Design & $\begin{array}{l}\text { Studies follow a validated } \\
\text { methodology }\end{array}$ & Informal papers \\
\hline
\end{tabular}




\begin{tabular}{|l|l|l|}
\hline Focus & $\begin{array}{l}\text { Studies focusing on KM, } \\
\text { knowledge mapping and } \\
\text { COVID-19 }\end{array}$ & $\begin{array}{l}\text { Studies with no relationship } \\
\text { to the research question }\end{array}$ \\
\hline
\end{tabular}

In addition, other articles and news items from the past few months of the pandemic outbreak were referenced; these were ones which focused on critical knowledge areas for managing COVID-19. A search for this information was conducted through various media platforms and outlets such as BBC News, NHS, CNN, The Guardian, The New York Times, Business Insider, The Telegraph, The Economist, Reuters, and The Financial Times. Kummitha (2020) noted that the use of media outlets to identify novel mechanisms can been useful in understanding trends and approaches adopted by various governments. The use of research articles, WHO situation reports and news from media outlets formed a basis for triangulating the data.

Table 4: Critical COVID-19 knowledge areas based on literature findings

\begin{tabular}{|c|c|c|c|c|c|c|c|}
\hline \multirow[t]{2}{*}{ Reference } & \multicolumn{7}{|c|}{ Critical knowledge areas } \\
\hline & $\begin{array}{l}\text { Cleaning and } \\
\text { disinfection }\end{array}$ & $\begin{array}{l}\text { Potential } \\
\text { COVID-19 } \\
\text { transmission } \\
\text { in health } \\
\text { and other } \\
\text { care settings }\end{array}$ & $\begin{array}{l}\text { Training, } \\
\text { education and } \\
\text { communication }\end{array}$ & $\begin{array}{l}\text { Reporting } \\
\text { guidance } \\
\& \\
\text { updates }\end{array}$ & Testing & $\begin{array}{l}\text { Infection } \\
\text { control } \\
\text { measures }\end{array}$ & $\begin{array}{l}\text { Improving and } \\
\text { increasing } \\
\text { access to PPE }\end{array}$ \\
\hline $\begin{array}{l}\text { Al Hakim et } \\
\text { al. }(2020)\end{array}$ & & & $\mathrm{X}$ & & & & \\
\hline $\begin{array}{l}\text { Al-Hity et al. } \\
(2021)\end{array}$ & & & & & & & $\mathrm{X}$ \\
\hline $\begin{array}{l}\text { Anttiroiko } \\
(2021)\end{array}$ & & $\mathrm{X}$ & $\mathrm{X}$ & & & & \\
\hline $\begin{array}{l}\text { Bhamra et al. } \\
(2021)\end{array}$ & & & & & & & $\mathrm{X}$ \\
\hline $\begin{array}{l}\text { Elavarasan and } \\
\text { Pugazhendhi } \\
(2020)\end{array}$ & & & & $\mathrm{X}$ & & & \\
\hline $\begin{array}{l}\text { Holmgren et } \\
\text { al. (2020) }\end{array}$ & & & & $\mathrm{X}$ & & & \\
\hline $\begin{array}{l}\text { Islam et al. } \\
(2020)\end{array}$ & $\mathrm{x}$ & & & & & $\mathrm{X}$ & $\mathrm{X}$ \\
\hline $\begin{array}{l}\text { La Marca et al. } \\
(2020)\end{array}$ & & & & & $\mathrm{X}$ & & \\
\hline $\begin{array}{l}\text { Nathavitharana } \\
\text { et al. }(2020)\end{array}$ & $\mathrm{X}$ & $\mathrm{X}$ & & & $\mathrm{X}$ & & \\
\hline $\begin{array}{l}\text { Parra et al. } \\
(2021)\end{array}$ & $\mathrm{X}$ & $\mathrm{X}$ & & & & & \\
\hline $\begin{array}{l}\text { Rowan and } \\
\text { Laffey (2020) }\end{array}$ & $\mathrm{X}$ & & & & & & \\
\hline $\begin{array}{l}\text { Swanson and } \\
\text { Santamaria } \\
(2021)\end{array}$ & & & & & & & $\mathrm{X}$ \\
\hline $\begin{array}{l}\text { Vaishya et al. } \\
(2020)\end{array}$ & & & & $\mathrm{X}$ & & & \\
\hline $\begin{array}{l}\text { Wu et al. } \\
(2020 \mathrm{a})\end{array}$ & $\mathrm{X}$ & & & & & & \\
\hline
\end{tabular}




\begin{tabular}{|l|c|l|l|l|l|l|l|}
\hline $\begin{array}{l}\text { Yang et al. } \\
2020\end{array}$ & $\mathrm{X}$ & & $\mathrm{X}$ & & & $\mathrm{X}$ & \\
\hline $\begin{array}{l}\text { Zhou et } \\
\text { al.(2020b) }\end{array}$ & $\mathrm{X}$ & & & & & & \\
\hline
\end{tabular}

\section{Findings and discussion}

The analysis of the review revealed seven critical knowledge areas that decision-makers need to be aware of in addressing COVID-19 crisis. They are reducing and minimising the risk of transmission of COVID-19; providing information about testing; improving access to PPE; enhancing infection control measures; facilitating reporting and communication; enhancing cleaning and disinfection processes. This is presented in a concept knowledge map as shown in Figure 1. Each of these critical knowledge areas is detailed below along with the know-how in Table 5. The findings indicate that knowledge mapping related to the COVID-19 pandemic has the potential to improve planning, treatment and control of the pandemic, and to enhance decision-making. 
AAM- Journal of Knowledge Management, DOI: 10.1108/JKM-01-2021-0083

Critical knowledge areas for managing the COVID-19 pandemic

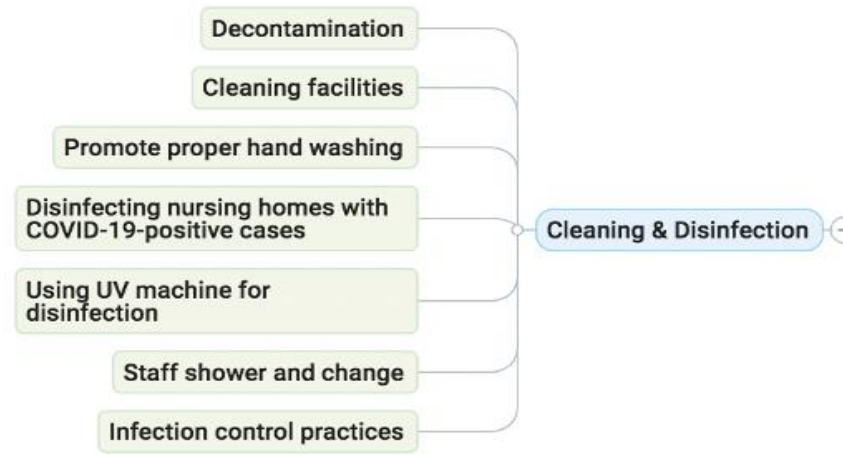

Decontaminate hands with ABHR

Use disposable, single-use

tissues

Catch it, bin it, kill it'

\section{Minimizing potential COVID-19} transmission in health and oth

Early recognition, isolation,
notification and molecular

diagnostics.

Online PPE training webinar/

supplies/ disinfection \& guidance

Guidelines on universal masking/ face coverings/gloves.

Assembling toolkit for best practice, sanitising, staffing, etc.

Supply hotline

Providing resources

Emergency response

Improving and increasing access

to PPE

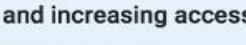

Infection prevention and control measures 19 management

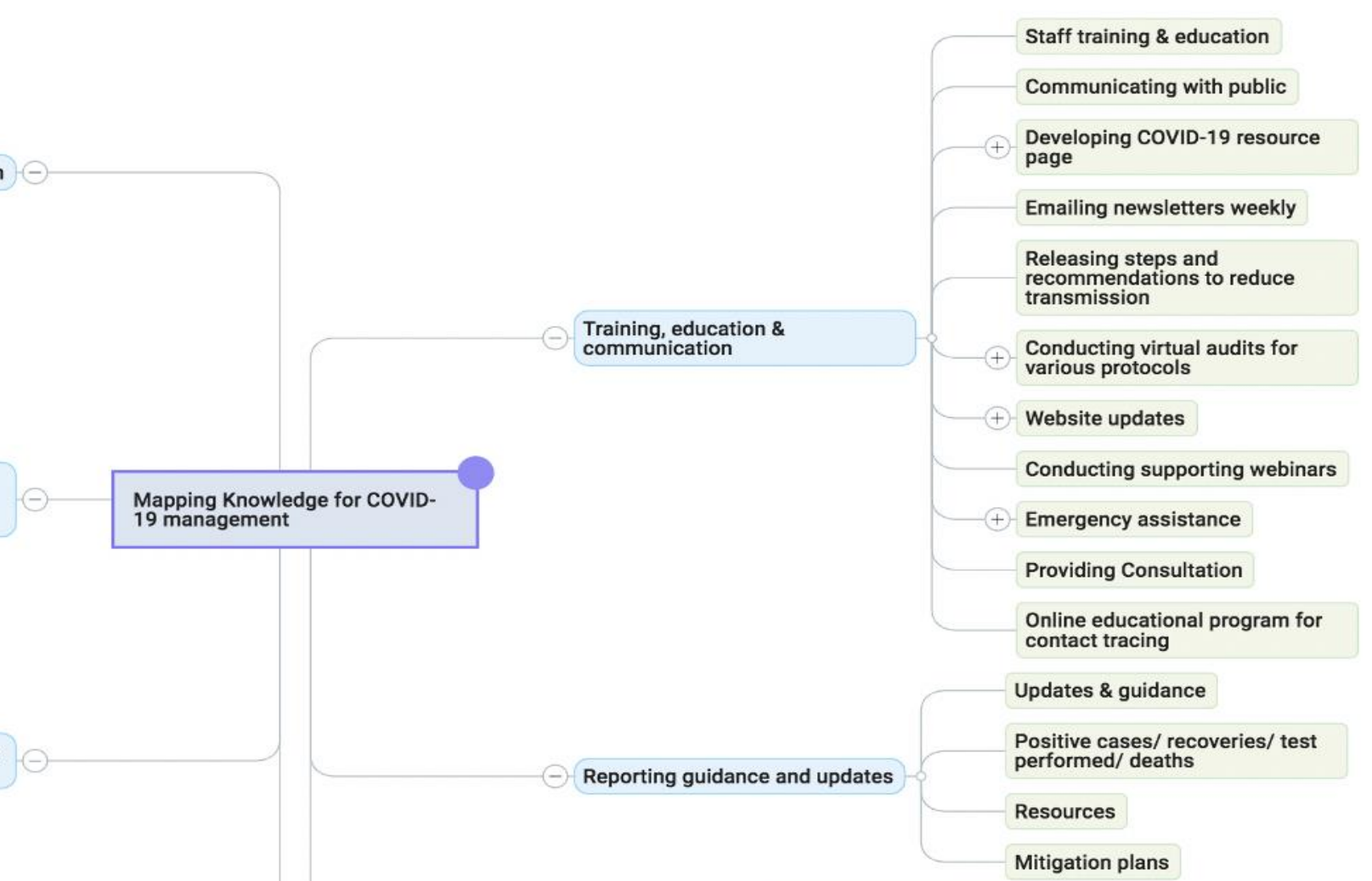

Testing

\section{Testing strategies/ priorities/}

kits/ sites \& option

Strike teams

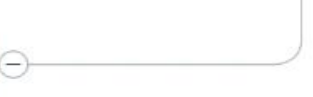

Boosting capacity

Figure 1: Map of critical knowledge to manage the COVID-19 pandemic (based on literature findings) 
Table 5: COVID-19 critical knowledge areas

\begin{tabular}{|c|c|}
\hline Know & How \\
\hline Cleaning and disinfection & $\begin{array}{l}\text { Decontamination } \\
\text { - } \quad \text { Offering decontamination systems for hospitals, nursing homes and } \\
\text { other healthcare providers. } \\
\text { - } \quad \text { Distributing alcohol hand rub and COVID-19 cleaning solution to } \\
\text { long-term care facilities when required. } \\
\text { - } \quad \text { Providing access to free N95 sterilisation for healthcare facilities. } \\
\text { Cleaning facilities } \\
\text { - } \quad \text { Providing cleaning services for long-term care facilities. } \\
\text { - } \quad \text { Providing all environmental services staff with laminated daily and } \\
\text { terminal room cleaning checklists. } \\
\text { Promote proper hand washing } \\
\text { - } \quad \text { Providing resource, including poster, to promote and display proper } \\
\text { handwashing across healthcare facilities. } \\
\text { Disinfecting nursing homes with COVID-19-positive cases } \\
\text { - } \text { Offering training for staff on the techniques of donning and doffing } \\
\text { PPE as well as sanitise and disinfect nursing homes that have COVID- } \\
\text { 19-positive residents and/or employees. } \\
\text { Using UV machine for disinfection } \\
\text { - Uses a UV machine to disinfect face shields, N95 masks, iPads, nurse } \\
\text { - } \text { - } \text { Infection control preys, and any other needed items. } \\
\text { - Staff shower and change at the end of shifts in designated areas at the } \\
\text { facility before leaving unit to reduce spread of COVID-19 in the } \\
\text { community or at homes. } \\
\text { other external sources. }\end{array}$ \\
\hline $\begin{array}{l}\text { Training and education } \& \\
\text { communication }\end{array}$ & $\begin{array}{l}\text { - Conducting frequent staff education and requesting that staff only } \\
\text { work in their facility and not others. } \\
\text { Continually communicating with families on pandemic activities, } \\
\text { including testing as required. } \\
\text { - Developing a COVID-19 resource page, updated daily with } \\
\text { information regarding regulations, infection control, PPE and other } \\
\text { control and prevention information } \\
\text { Preparing weekly member newsletters and email blasts on COVID-19- } \\
\text { related resources and events. } \\
\text { Releasing the environmental steps to reduce indoor COVID-19 } \\
\text { transmission, with recommendations and resources for facilities to } \\
\text { follow to minimise the risk of virus transmission through indoor } \\
\text { airflows. } \\
\text { Conducting virtual audits using video to verify the cleaning protocols } \\
\text { and use of PPE in nursing homes, assisting living facilities and } \\
\text { immediate care facilities. }\end{array}$ \\
\hline
\end{tabular}




\begin{tabular}{|c|c|}
\hline & 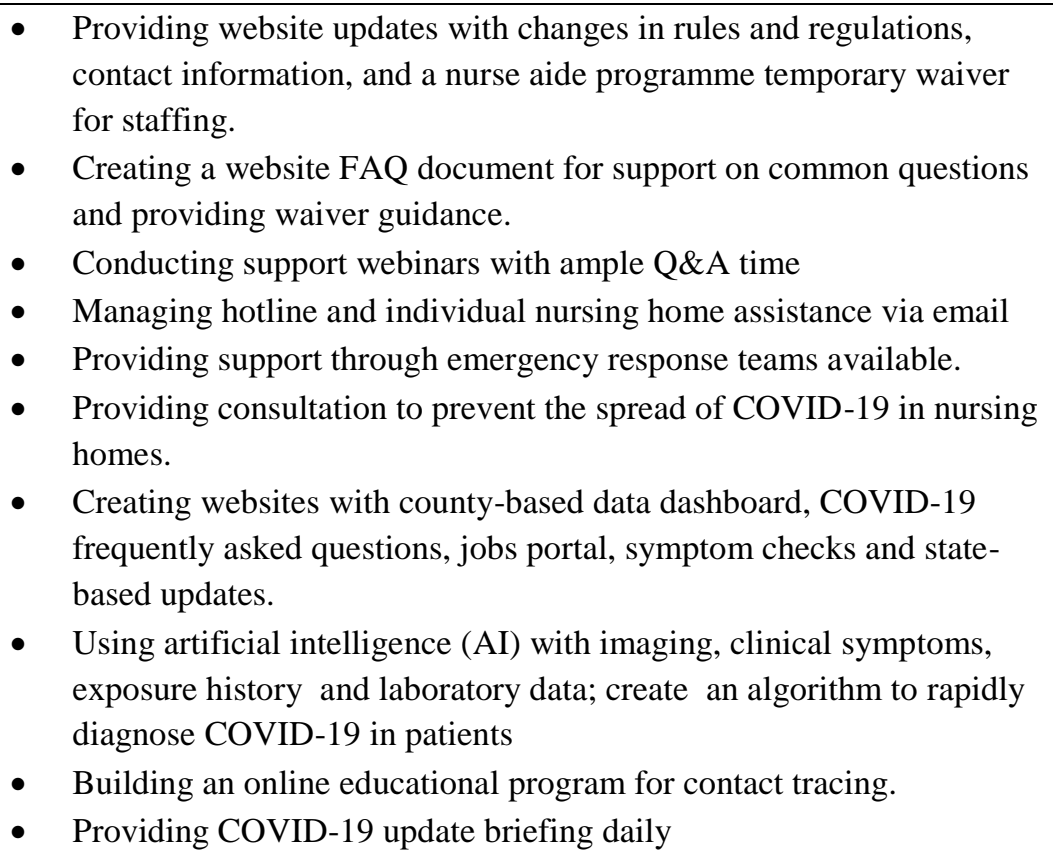 \\
\hline $\begin{array}{l}\text { Reporting/guidance/mandated } \\
\text { reporting }\end{array}$ & 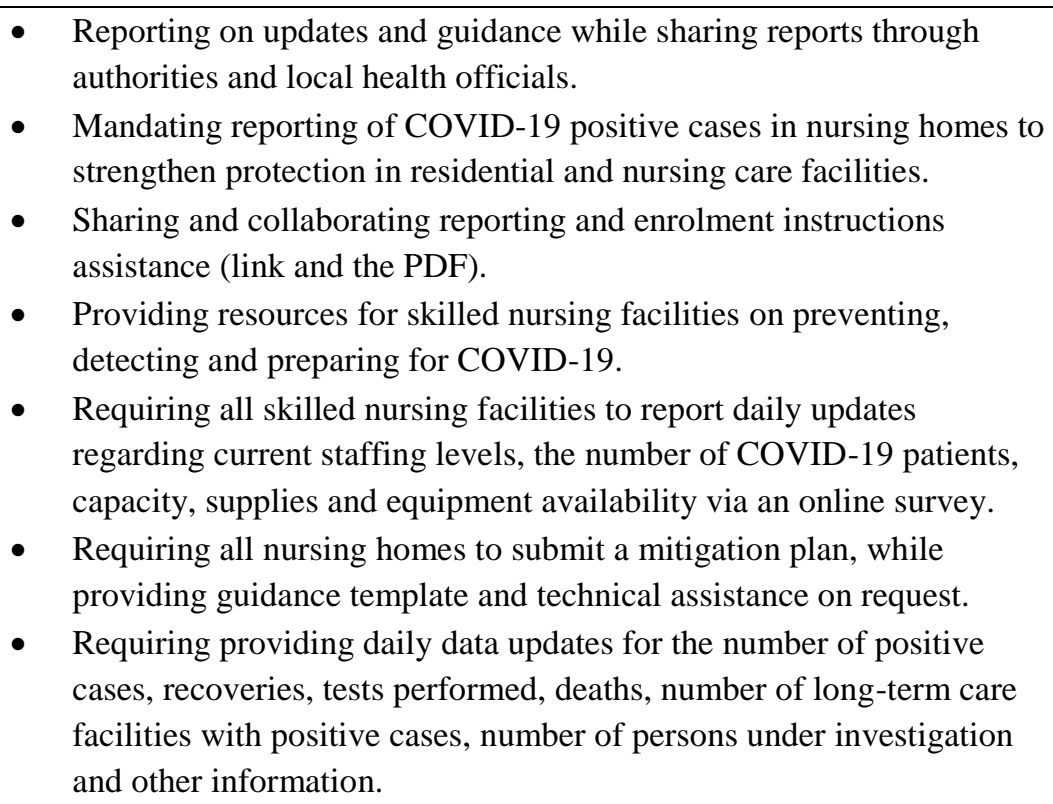 \\
\hline Testing & 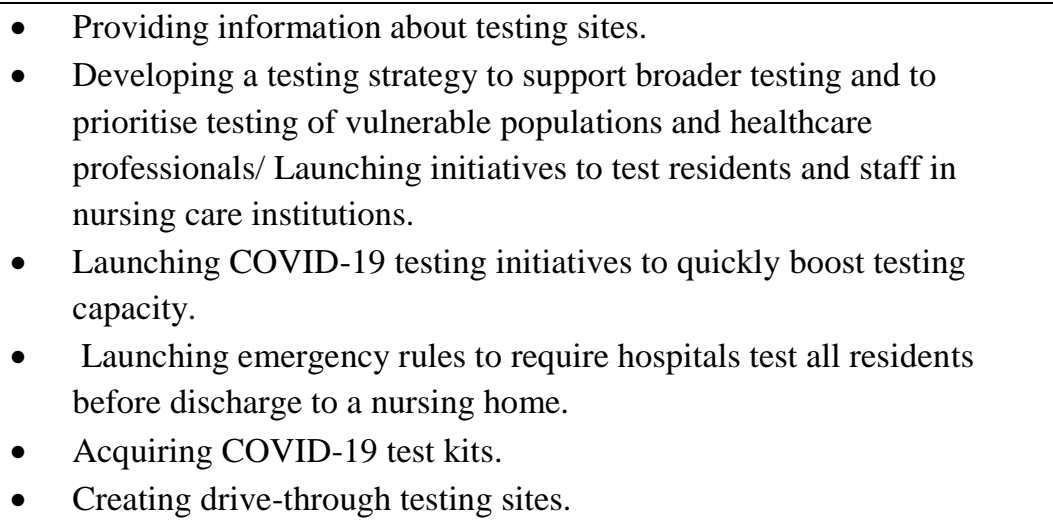 \\
\hline
\end{tabular}




\begin{tabular}{|c|c|}
\hline $\begin{array}{l}\text { Infection preventions and } \\
\text { control measures and } \\
\text { guidelines }\end{array}$ & $\begin{array}{l}\text { - Providing resources for skilled nursing facilities to help prevent, detect } \\
\text { and prepare for COVID-19. } \\
\text { - Creating COVID-19-dedicated web pages. } \\
\text { - Creating strike teams to conduct testing in nursing homes when } \\
\text { potential or positive COVID-19 cases are seen in residents or staff } \\
\text { members } \\
\text { - Providing guidance on emergency response (e.g., emergency teams, } \\
\text { supplies and equipment) to overburdened nursing homes. } \\
\text { - Establishing and educating staff regarding its COVID-19 response } \\
\text { strategic plan. }\end{array}$ \\
\hline $\begin{array}{l}\text { Improving and increasing } \\
\text { access to PPE }\end{array}$ & $\begin{array}{l}\text { - Creating an online guidance for available PPE supplies. } \\
\text { - } \quad \text { Providing guidelines on universal masking and use of face coverings } \\
\text { for residents, healthcare workers, staff and visitors in long-term care } \\
\text { facilities. } \\
\text { - } \quad \text { Conducting a PPE train-the-trainer webinars. } \\
\text { - } \quad \text { Making major push for PPE to support healthcare workers in long- } \\
\text { - Taking the lead in coordination between nursing homes and the } \\
\text { - } \quad \text { Assemergency management authorities for distribution of PPE supplies. } \\
\text { PPE. } \\
\text { - Creating a PPE supply hotline informing nursing homes when supplies } \\
\text { become available. } \\
\text { - } \text { Assembling a PPE wholesale supplier registry public listing. } \\
\text { - Establishing PPE reporting portal to monitor PPE levels. } \\
\text { optimise healthcare resources. }\end{array}$ \\
\hline $\begin{array}{l}\text { Minimising potential COVID- } \\
19 \text { transmission in health and } \\
\text { other care settings. }\end{array}$ & $\begin{array}{l}\text { Decontaminate hands with alcohol-based hand rub (ABHR) for all } \\
\text { staff, patients and visitors when entering and leaving areas where } \\
\text { patient care is being delivered. } \\
\text { Wherever possible, patients, staff and visitors need to use disposable, } \\
\text { single-use tissues to cover the nose and mouth when sneezing, } \\
\text { coughing or wiping and blowing the nose - used tissues should be } \\
\text { disposed of promptly in the nearest waste bin. } \\
\text { Also, tissues, waste bins (lined and foot operated) and hand hygiene } \\
\text { facilities should be available for patients, visitors and staff }\end{array}$ \\
\hline
\end{tabular}

\section{Cleaning and disinfection}

Evaluation surface and air contamination in relation to SARS-CoV-2 during the COVID-19 pandemic revealed that surface contamination was detected on a range of items. Computer keyboards, chairs and alcohol dispensers had the highest proportion of positive/suspected SASCoV-2 samples (Zhou et al., 2020b). The environment around patients with COVID-19 is widely contaminated. Therefore, basic environmental hygiene and disinfection measures should be put in place (Wu et al., 2020a). Islam et al. (2020) reviewed global COVID-19 infection prevention and control (IPC) guidelines put together by organisations such as the WHO, the US Center for Disease Control and Prevention (CDC), and the European Centre for Disease Prevention and Control (ECDC) and concluded that in all guidelines alcohol-based hand sanitisers (ABHS) have been prioritised whenever available. To reduce room 
contamination in hospital settings, all of the guidelines recommend routine cleaning and disinfection of surfaces using disinfectants. The Chinese guidelines also recommend the use of aerosol disinfectants using an air steriliser and pressure steam sterilisation. Guidelines from Australia, China and the United Kingdom recommend incinerating or sterilising patients' clothing, bedding and utensils (Islam et al., 2020). Wu et al. (2020a) demonstrated the effectiveness of disinfection. However, the study suggested that environmental surface disinfection should include wiping in an "S"-shaped motion and that surfaces should not be rewiped once they have already been cleaned. Additionally, the frequency of disinfection should be increased appropriately, to at least three times per day: twice during the day and once at night (disinfection should be undertaken at any time where there is obvious contamination). Moreover, cleaners should undergo ongoing training to ensure that they are qualified for their job.

Accordingly, CMS (2020) suggests offering decontamination systems for hospitals, nursing homes and other healthcare providers, in addition to distributing alcohol hand rub and COVID19 cleaning solution to long-term care facilities when required. Providing cleaning services for long-term care facilities, as well as providing all environmental services staff with laminated daily and terminal room cleaning checklists, is suggested. These could be kept on carts and referred to in order to ensure that all cleaning steps have been completed (CMS, 2020). Knowledge maps can be used to provide knowledge of techniques, resources required and guidance on various cleaning and disinfection requirements (Brahami et al., 2013; CMS, 2020). Knowledge maps represent an excellent way to capture and share explicit knowledge in organisational contexts.

\section{Minimising the potential of COVID-19 transmission in health and other care settings}

According to the findings of Parra et al. (2021) and Nathavitharana et al. (2020), infection prevention efforts could benefit from the unprecedented amounts of data, information and knowledge on COVID-19 that are being generated and shared. Successful examples of the rapid intensification of infection prevention measures to decrease transmission in healthcare facilities should be emulated. For instance, the hospital authority of Hong Kong implemented a bundle of measures focused on early recognition, isolation, notification and molecular diagnostics for people who were being evaluated for COVID-19. They subsequently broadened the clinical and epidemiological criteria of surveillance as the outbreak evolved and intensified PPE recommendations for all healthcare workers (HCW) (face masks for all and N95 respirators for those performing aerosol-generating procedures), which appears to have resulted in no cases of $\mathrm{HCW}$ infection or nosocomial transmission.

Speel et al. (1999) define knowledge mapping as the process, methods and tools for analysing knowledge areas in order to discover features or meaning and to visualise these in a comprehensive, transparent form, such that the business-relevant features are clearly highlighted. Knowledge maps are created by transferring certain aspects of knowledge into a graphical form that is easily understandable compared to written and oral communication modes. Knowledge maps can be used to communicate this important information to patients and healthcare staff members and visitors. For example, patients, staff and visitors should be encouraged to minimise the potential for COVID-19 transmission by deploying knowledge maps to communicate good respiratory hygiene measures, including using disposable, singleuse tissues to cover the nose and mouth when sneezing, coughing or wiping and blowing the nose - used tissues should be disposed of promptly in the nearest waste bin (CMS, 2020). They 
can also help to visualise how hands should be cleaned (e.g., using soap and water, if possible, otherwise using ABHS) after coughing, sneezing, using tissues or after any contact with respiratory secretions and contaminated objects. Patients should be encouraged to keep their hands away from their eyes, mouth and nose (DHSC, 2020; CMS, 2020). This helps in minimising the potential for COVID-19 transmission in health and other care settings.

\section{Training, education and communication}

According to Anttiroiko (2021), an agile-adaptive approach, a policy of transparency in communicating risk, and citizens' voluntary cooperation were all critical to the success of South Korea's anti-contagion policy. It is important to incorporate the community into a response to a public health emergency (PHE), and to educate people about public health prevention standards, which can improve the ability to cope with a pandemic (Yang et al., 2020). PHS (2021) states that organisations and employers must ensure that training in IPC measures are provided to all staff, including on the correct use of PPE (including a face fit check if wearing a filtering face piece (FFP3), respirator and the correct technique for putting on and removing (donning/doffing) it safely). Knowledge mapping can be used to communicate with families about pandemic-related responses such as testing as required (CMS, 2020). These knowledge-sharing techniques should be updated regularly with information and knowledge regarding regulations, infection control and PPE. Smart technologies can also be used to conduct virtual audits using video to verify cleaning protocols and the use of PPE in nursing homes, assisted living facilities and immediate care facilities. The creation of a website FAQ document for support on common questions and provision of waiver guidance is also recommended. These knowledge maps can also make use of artificial intelligence (AI) with imaging, clinical symptoms, exposure history and laboratory data, creating an algorithm with which to rapidly diagnose COVID-19 in patients. Al Hakim et al. (2020) also concluded that the support of technology through the use of AI can be expected to enable comprehensive, adaptive and objective knowledge mapping for organisations.

\section{Reporting guidance and updates}

Holmgren et al. (2020) noted that an effective pandemic response requires rapid, accurate information and knowledge sharing between hospitals and public health agencies. Advancing these capabilities requires information and knowledge to be reported and shared, including lab results and syndromic surveillance data, among various public and private health agencies. Such reporting requirements were originally intended to allow public health agencies to monitor and react quickly to potential infectious disease and influenza outbreaks. However, hospitals may experience technical or administrative barriers to this kind of reporting, and electronic hospital reporting to public health agencies has been inconsistent during the COVID19. The resulting information and knowledge gaps can exacerbate the public health challenges in relation to identifying infection, quarantining and contact-tracing potentially infected individuals and can preclude a timely response in infected areas. Data characterising the extent of occupational infections in HCWs during acute and chronic epidemics are often lacking and subject to wide variability in reporting, which limits their impact (Elavarasan and Pugazhendhi, 2020; Vaishya et al., 2020). Moreover, Nathavitharana et al. (2020) noted that transparency in data sharing and reporting will facilitate urgent action to replenish and sustain resources such as PPE and enable institutions to share and adopt successful infection prevention strategies. With regard to COVID-19, this reporting is designed to ensure that the information necessary to respond to the COVID-19 outbreak and to provide resources and support is available (CMS 2020; PHE, 2021). Knowledge maps can be used to share reports, updates and guidance 
through authorities and local health officials, including daily updates regarding current staffing levels, the number of COVID-19 patients, capacity, supplies and the availability of equipment. Moreover, knowledge maps can also be used to share mitigation plans, guidance templates and technical assistance along with shared and collaborative reports (e.g., through sharing links or PDF).

\section{Testing}

The approach to initial management should focus on early recognition of suspect cases, immediate isolation and the institution of infection control measures. Moreover, the decision to discontinue infection control precautions for patients with COVID-19 should be made on a case-by-case basis in consultation with experts in infection prevention and control, and public health officials. Factors which should inform this decision include resolution of clinical signs and symptoms and negative results of reverse-transcription polymerase chain reaction (RTPCR) testing for severe acute respiratory syndrome coronavirus 2 (SARS-CoV-2) from two sequential paired nasopharyngeal and throat specimens (McIntosh et al., 2020). Knowledge of COVID-19 testing includes providing information about testing sites, developing a testing strategy to support broader testing and to prioritise testing of vulnerable populations and healthcare professionals, providing knowledge and information about acquiring COVID-19 test kits, in addition to developing a set of priorities and recommendations with to the aim of facilitating a rapid increase in testing for COVID-19, utilising all testing sites and platforms available (CMS, 2020).

Nathavitharana et al. (2020) noted that scaled-up testing in South Korea has helped limit the spread and the negative effects of COVID-19. The use of drive-through testing centres has enabled safe and efficient testing, while minimising the risk to HCWs and eliminating the possibility of cross-infection among people being tested. Therefore, knowledge mapping can be used to provide information and knowledge about testing sites and to launch initiatives to test residents and staff in nursing care institutions, whilst also allowing for the option of having a lab come to a particular location to undertake testing or obtaining supplies for on-site testing. Knowledge maps may also assist when launching COVID-19 testing initiatives to quickly boost testing capacity to ensure there is enough capacity and there are enough supplies to administer a significantly greater number of tests (CMS, 2020). PHE (2021) states that organisations and employers, including NHS Trusts, NHS Boards, Health and Social Care Trusts (Northern Ireland), Local Authorities, and Independent Sector providers, through their Chief Executive Officer (CEO) or equivalent, must ensure that testing strategies are in place with a local policy for the response if transmission rates of COVID-19 increase. Furthermore, according to La Marca et al. (2020), an understanding of the application and diagnostic performance of the different testing approaches for SARS-Cov-2 is essential in the fight against this pandemic.

\section{Infection prevention and control measures and guidelines}

Global IPC guidelines (e.g., the Department of Health, Australia, the Bureau of Disease Prevention and Control of the National Health Commission of the People's Republic of China, the CDC, the ECDC, Public Health England, and the WHO) have published COVID-19 IPC guidelines that have targeted health administrators, HCPs, or public health units to implement IPC measures (Islam et al., 2020). 
According to Anttiroiko (2021), containment and mitigation strategies are designed to slow the speed of spread of a virus by suppressing the outbreak and by slowing down the disease. As the coronavirus continues to spread and the testing rates vary from one country to another, public health officials should shift from a containment mindset to a mitigation mindset. According to Yang et al. (2020), the current main means of prevention and control are cutting off the route of transmission. However, such methods are very costly, involve the need to identify close contacts through various channels, and may lead to large numbers of people being isolated, even posing the risk of global economic downturn, currency devaluation in many countries and high mortality rates. Therefore, controlling and managing the COVID-19 outbreak requires the provision of resources for skilled nursing facilities to help prevent, to detect and to prepare for COVID-19 (CMS, 2020). Sharing knowledge regarding IPC measures in practice includes suspected source control, the use of PPE, rapid diagnosis, physical distancing, isolation, investigation and follow-up of close contacts. All the guidelines available around the world include administrative control, environmental control and PPE, and the guidelines in Australia, from the WHO, and the CDC (Islam et al., 2020). IPC measures in healthcare settings include maintaining separation in space and or time between suspected and confirmed COVID-19 patients, educating staff, patients and visitors about standard infection control precautions (SICPs) and transmission-based precautions (TBPs), and prompt implementation of TBPs to limit transmission. They may also include restricting access for all but essential visitors to all areas of a healthcare facility, instructing staff members with symptoms to stay at home and not come to work until their symptoms resolve, in addition to planning and implementing strategies for surge capacity (CMS, 2020; DHSC, 2020). Knowledge mapping can be used to create web pages dedicated to COVID-19 information dissemination, with links to details of emergency response/strike teams (CMS, 2020). Thus, it may facilitate the knowledge sharing needed to enable early recognition or reporting of cases, early assessment or triaging of cases and the implementation of control measures.

\section{Improving and increasing access to PPE}

Preliminary data from the initial outbreak of COVID-19 in Wuhan suggested almost one-third of infected patients were health professionals ( $\mathrm{Li}$ et al., 2020). Given the high rates of transmission of COVID-19, there have been moves towards the use of universal PPE. Accordingly, Nathavitharana et al, (2020) noted that there has been a massive and rapid increase in the need for PPE globally because overwhelmed health systems have been having to care for large numbers of patients with suspected or confirmed COVID-19. However, the acute shortage of PPE is a challenge and has resulted in an urgent need to embrace innovation in terms of infection prevention (Nathavitharana et al., 2020). Due to the global shortages in the supply of PPE, almost all of the guidelines have revised their initial recommendations related to PPE use. Of the six guidelines reviewed by Islam et al. (2020), five recommend the reuse of PPE following the manufacturers' instructions. Alongside sufficient provision of equipment and clear guidance, knowledge and adherence to the appropriate use of PPE among health professionals is required. Adequate PPE is, therefore, of paramount importance in ensuring the safety of health professionals working on the frontline, particularly those participating in aerosol-generating procedures (AGPs) (Bhamra et al., 2021). Researchers widely believe that mortality would be reduced if the medical supply and PPE supply chains were protected (Swanson and Santamaria, 2021). Therefore, both the appropriate use and availability of PPE are imperative components in building a defence barrier against a highly infectious and potentially fatal virus (Yang et al., 2020; Al-Hity et al., 2021). 
Nathavitharana et al. (2020) highlighted the potential for innovation and knowledge sharing to address PPE shortages, in turn enhancing HCWs' safety in the current COVID-19 pandemic. Contingency planning for PPE stock shortages is also important. However, providing solutions for the shortages in the supply chain for one-time-use PPE is extremely complex. Solutions include the use of smart communication channels to improve supply chains and stock management, bespoke production of PPE to meets shortfalls, along with the least preferred option, namely the use of sterilisation or high-level disinfection for PPE reprocessing (Rowan and Laffey 2020; Parra et al., 2021). Therefore, the use of smart software and networking with various distribution channels is recommended to meet shortfalls in PPE and infection prevention and control (IPC) methods.

Knowledge maps can be used to create online PPE, employment and material resource guides for providers to enable them to find available supplies, disinfectants, PPE and employer/employee guidance. They can also be used to provide guidelines on universal masking and the use of face coverings for residents, healthcare workers, staff and visitors in long-term care facilities (CMS, 2020; Parra et al., 2021). A major push is required in relation to PPE to support healthcare workers in long-term care facilities. Moreover, it can take the lead in coordination between nursing homes and the emergency management authorities for the distribution of PPE supplies.

\section{Conclusion and recommendations}

The ability to manage the COVID-19 pandemic is contingent upon the ability to effectively manage its knowledge resources. This implies the ability to correctly capture, share, apply and use the available knowledge resources to enhance decision-making (Rialti et al., 2020). Balaid et al. (2013) noted that the most important responsibilities of KM are to envisage knowledge for knowledge seekers. Given the novelty of the COVID-19 disease, sharing other people's experiences of robust and clear practical procedures is ideal to familiarise healthcare professionals with COVID-19, especially in terms of hands-on best practice. The cost of not investing in effective knowledge management techniques, including knowledge mapping, is now widely apparent in the management of the outbreak of the pandemic (Rialti et al., 2020). Knowledge maps illustrate relationships between procedures, concepts and competency and provide easy and effective access to knowledge sources (Watthananon and Mingkhwan, 2012). Therefore, a knowledge map visualises the knowledge flow throughout the enterprise and helps to steer both tacit and explicit knowledge (Balaid et al., 2013). Knowledge maps do not provide but rather indicate tools for knowledge and, thus, "knowledge maps are guides, not repositories" (Davenport and Prusak, 1998). Rapid scaling-up of diagnostic testing capacity, as well as bundles for cleaning, infection prevention and disinfection interventions, including universal masking and drive-through testing, could help to address PPE shortage issues, minimise disease transmission in health and other care settings, as well as safeguarding HCWs and the patients they serve in the current COVID-19 pandemic.

Knowledge maps are excellent ways to capture and share explicit knowledge in organisational contexts. Therefore, knowledge mapping using various graphical presentations of text, stories, models, numbers or abstract symbols between map makers and map users offers various opportunities to help to tackle COVID-19. Using knowledge mapping techniques allows large and complex sets of knowledge resources to be acquired and navigated more easily (Balaid et al., 2013). This is especially important for managing COVID-19 due to the need to manage huge amounts of data from mobile applications, official websites, social media, virtual communities, instant messaging and social bookmarking (Nathavitharana et al., 2020). Thus, 
using knowledge mapping techniques in order to manage and share knowledge related to COVID-19 can enhance the arrangement and implementation of necessary control measures to avoid the further spread of the virus and tackle the impacts of the pandemic.

This study has developed a concept knowledge map for managing the COVID-19 pandemic, identifying seven areas of critical knowledge that decision-makers should be aware of. The findings indicate that knowledge mapping related to the COVID-19 pandemic has the potential to improve planning, treatment and control of the pandemic, and to enhance decision making. This study concluded that knowledge mapping related to COVID-19 assists in reducing and minimising the risk of transmission of COVID-19 in hospitals, healthcare settings and other care settings. It also provides information about testing and enhancing testing capacity. It improves and increases access to PPE. It enhances infection control measures by sharing necessary information about strike teams' roles in order to provide on-site medical triage, supplies and equipment to overburdened nursing homes in order to slow the spread of the virus among the most vulnerable in the population. It facilitates and supports reporting, training, education and communication, in addition to enhancing and enabling proper cleaning and disinfection processes.

This study fills the gap in the existing literature and contributes to concept mapping and the sharing of knowledge by identifying and evaluating critical knowledge areas for managing the COVID-19 pandemic and preparing for future emergencies. With the seven critical knowledge areas revealed, it provides explicit representation of know-how for managing the COVID-19 pandemic which facilitates access to COVID-19-related knowledge for various decisionmakers. The knowledge mapping approach is perceived to improve and enhance knowledge management both within an organisation and externally with stakeholders and customers (Lin et al., 2006).

The study advances the literature on knowledge management and builds a theoretical link with the management of public health emergencies. In addition, the findings support the theoretical position that knowledge maps facilitate decision-making and help users to identify critical knowledge areas easily and effectively. Utilising knowledge mapping offers two advantages in terms of managing and controlling the COVID-19 outbreak. Firstly, knowledge maps are represented in simple, clear, visual ways within the context of a knowledge management system. Secondly, the mapping methodology helps users to identify the most critical and easily available knowledge areas which can contribute to effectively controlling the pandemic.

The study offers valuable insights into key and critical knowledge areas decision makers need to be aware of in order to address the COVID-19 crisis effectively. For example, the results have demonstrated that effective knowledge sharing, and knowledge mapping can address PPE shortages, in turn enhancing HCWs' safety in the current COVID-19 pandemic. In other words, knowledge maps can be an effective knowledge-sharing tool for the dissemination of reports, guidance, and for collaboration in order to combine the conclusions of varying reports, thus helping to minimise the potential of COVID-19 transmission and to control the pandemic.

The paper contributes to both theory and practice in the fields of knowledge management and provides practical suggestions for the effective management of the COVID-19 pandemic. This 
is the first study to identify the critical knowledge areas for managing COVID-19. This study has further implications in terms of enabling a discussion of the new paradigm of emergent knowledge mapping strategies for public health emergencies.

Encouraging and promoting work within and between multidisciplinary health professional teams is recommended in terms of developing strategies and policies that are shared by healthcare stakeholders. Table 6 sets out the implications for decision-makers and KM practitioners within public and private sector organisations in order to encourage them to rethink and act.

Table 6: Implications for decision-makers and KM practitioners within public and private sector organisations

\begin{tabular}{l} 
Implications \\
\hline Using smartphone for \\
knowledge detection
\end{tabular}

Recommendations for decision-makers and KM practitioners

knowledge detection

Smartphone is a ubiquitous tool that leverages the power of the internet like no other. It provides the ability to directly reach and engage with a significant proportion of the world's population in near real time, which has immense potential for addressing COVID-19 outbreaks via rapid detection. Therefore, more efforts need to be directed towards unpacking smartphone potential through efficient use and rapid detection of real time big data.

\section{Epidemiological information sharing platforms}

More effort and focus need to be directed towards supporting epidemiological information sharing strategies. Epidemiological data must be gathered through a steady and reliable approach, and establish a multi-department dynamic information sharing system, which will effectively and comprehensively improve the ability of medical institutions in metropolises for epidemic prevention and control.

\begin{tabular}{|c|c|}
\hline $\begin{array}{l}\text { Multi-department } \\
\text { monitoring platform }\end{array}$ & $\begin{array}{l}\text { Governments need to establish a multi-department platform to facilitate dynamic } \\
\text { information monitoring, to improve the ability to prevent and control the virus } \\
\text { spread. }\end{array}$ \\
\hline Public engagement & $\begin{array}{l}\text { Public-private-academia collaboration is necessary and is seen as a key to build } \\
\text { and implement more efficient tackling strategies. Therefore, creating an open } \\
\text { platform for sufficient use and share of data is required. }\end{array}$ \\
\hline $\begin{array}{l}\text { Knowledge discovery/ } \\
\text { extraction }\end{array}$ & $\begin{array}{l}\text { COVID-19-related data and information are unstructured, wide ranging in } \\
\text { complexity, length and use of technical terminology, making knowledge } \\
\text { discovery more challenging. Therefore, a number of text analytical tools that can } \\
\text { facilitate a unique opportunity to extract critical knowledge from textual data } \\
\text { sources and archives are required. }\end{array}$ \\
\hline Knowledge creation & $\begin{array}{l}\text { Provide and support unconventional and mature data storage, management, } \\
\text { analysis and visualisation tools and techniques needed for extracting knowledge } \\
\text { from a huge amount of data such as in the case of COVID-19. }\end{array}$ \\
\hline $\begin{array}{l}\text { Local-citizen-driven } \\
\text { strategies }\end{array}$ & $\begin{array}{l}\text { KM practitioners need to take into consideration the importance of the tacit local } \\
\text { knowledge of the regional citizens as it has a great impact on their social } \\
\text { behaviours. }\end{array}$ \\
\hline $\begin{array}{l}\text { Healthcare systems } \\
\text { knowledge capturing }\end{array}$ & $\begin{array}{l}\text { Healthcare systems need to facilitate the necessary software packages, and } \\
\text { intelligence and analytical capabilities systems for data mining and knowledge } \\
\text { capturing. }\end{array}$ \\
\hline Increase collaboration & $\begin{array}{l}\text { Managing COVID-19 knowledge requires collaboration between various bodies, } \\
\text { sectors and departments. Therefore, there is a need for cross-sector collaboration } \\
\text { to capture and share best and worst practices related to managing the COVID-19 } \\
\text { pandemic. }\end{array}$ \\
\hline Training & $\begin{array}{l}\text { It is necessary to train doctors and healthcare practitioners to enable them to } \\
\text { effectively manage real clinical challenges related to COVID-19. Thus, it is } \\
\text { essential to provide them with as much updated knowledge as possible. }\end{array}$ \\
\hline $\begin{array}{l}\text { International } \\
\text { collaboration }\end{array}$ & $\begin{array}{l}\text { Partnership with foreign business with the same issues will accelerate the project. } \\
\text { Therefore, a joint international effort is advisable to face the COVID-19 fallout } \\
\text { and establish pathways for crisis management. }\end{array}$ \\
\hline
\end{tabular}




\begin{tabular}{ll}
\hline $\begin{array}{l}\text { Using the Cloud for } \\
\text { knowledge sharing }\end{array}$ & $\begin{array}{l}\text { Smart strategies, such as the cloud is considered a game-changer in these times } \\
\text { of uncertainty for many organisations. Therefore, cloud-based knowledge should } \\
\text { be used for knowledge sharing and transfer through various channels in real time. }\end{array}$ \\
\hline Digital transformation & $\begin{array}{l}\text { In response to COVID-19, organisations have adapted rapidly. Digital } \\
\text { transformation is becoming a norm; however, many productivity and security } \\
\text { issues and concerns are still arising and require robust addressing strategies. }\end{array}$ \\
\hline
\end{tabular}

While the study contributes to the area of inquiry, it also has certain limitations. The study considered only journal articles and government reports published between December 2019 and April 2021, and only those written in English; these factors may have led to the exclusion of useful sources of information. Book chapters, books, conference papers, and unpublished works were not considered. The study was carried out following a thorough review of the literature but further studies could usefully be carried out by involving public health sector stakeholders. Additionally, it would be informative to explore empirical studies focusing on knowledge mapping within the context of the COVID-19 pandemic on a global scale. This would help to identify similarities and differences in the responses in developed and developing countries. This could lead to the generation of benchmark data and guidelines on best practices in terms of mapping COVID-19 pandemic-related critical knowledge areas.

\section{Reference}

Abdalla, W., Suresh, S. and Renukappa, S., (2020), "Managing knowledge in the context of smart cities: An organizational cultural perspective", Journal of Entrepreneurship, Management and Innovation, Vol 16 No 4, pp. 47-85.

Agbehadji, I.E., Awuzie, B.O., Ngowi, A.B. and Millham, R.C., (2020), "Review of big data analytics, artificial intelligence and nature-inspired computing models towards accurate detection of COVID-19 pandemic cases and contact tracing", International journal of environmental research and public health, Vol 17 No 15, pp.5330.

Alavi, M. and Leidner, D.E. (2001), "Review: knowledge management and knowledge management systems: conceptual foundations and research issues", MIS Quarterly, Vol 25 No 1, pp. 107-136.

Al Hakim, S., Sensuse, D.I., Budi, I., Winarni, M.M. and Khusni, U., (2020), “An empirical study of knowledge mapping implementation in Indonesian organizational context", VINE Journal of Information and Knowledge Management Systems. Vol 51 No 5, pp. 773-791.

Al-Hity, S., Bhamra, N., Kumar, R., Gupta, K.K., Howard, J., Jolly, K. and Darr, A., (2021), "Personal protective equipment guidance during a global pandemic: A statistical analysis of National perceived confidence, knowledge and educational deficits amongst UK-based doctors", International Journal of Clinical Practice, pp.e14029.

Allam, Z., and Jones, D. S. (2020), "On the coronavirus (COVID-19) outbreak and the Smart City Network: universal data sharing standards coupled with artificial intelligence (AI) to benefit urban health monitoring and management", Healthcare, Vol 8 No 1, pp. 46-54.

Ambavi, H., Vaishnaw, K., Vyas, U., Tiwari, A. and Singh, M., (2020), "Covid Explorer: a multi-faceted AI-based search and visualization engine for COVID-19 information", In Proceedings of the 29th ACM International Conference on Information \& Knowledge Management, pp. 3365-3368. 
American Productivity \& Quality Center (APQC) (2018a), "APQC 4-Step Guide to Knowledge Mapping", [Online]. [Accessed 04 Apr 21]. Available at:< https://www.apqc.org/blog/4-step-guide-knowledge-mapping>.

American Productivity \& Quality Center (APQC) (2018b), "Getting Started with Knowledge Mapping", [Online]. [Accessed 13 Jan 21]. Available at:< https://www.apqc.org/resourcelibrary/resource-listing/getting-started-knowledge-mapping>.

Andersen, K.G., Rambaut, A., Lipkin, W.I., Holmes, E.C. and Garry, R.F., (2020), "The proximal origin of SARS-CoV-2", Nature medicine, Vol 26 No 4, pp.450-452.

Anttiroiko, A.V., (2021), "Successful government responses to the pandemic: Contextualizing national and urban responses to the COVID-19 outbreak in east and west", International Journal of E-Planning Research (IJEPR), Vol 10 No 2, pp.1-17.

Arshad, M.I., Khan, H.A., Aslam, B. and Khan, J.A., (2021), "Appraisal of One Health approach amid COVID-19 and zoonotic pandemics: insights for policy decision", Tropical Animal Health and Production, Vol 53 No 1, pp.1-2.

Balaid, A., Abd Rozan, M.Z., Hikmi, S.N. and Memon, J., (2016), "Knowledge maps: A systematic literature review and directions for future research", International Journal of Information Management, Vol 36 No 3, pp.451-475.

Balaid, A.S.S., Zibarzani, M. and Rozan, M.Z.A., (2013), "A comprehensive review of knowledge mapping techniques", Journal of Information Systems Research and Innovation (JISRI), Vol 3, pp.61-66.

Bamel, N., Pereira, V., Bamel, U. and Cappiello, G., (2021), "Knowledge management within a strategic alliances context: past, present and future", Journal of Knowledge Management, Vol 25 No 7, pp. 1782-1810.

Bamel, U. and Bamel, N. (2018), "Organizational resources, KM process capability and strategic flexibility: a dynamic resource-capability perspective", Journal of Knowledge Management, Vol 22 No 7, pp. 1555-1572.

Brahami, M., Atmani, B. and Matta, N., (2013), "Dynamic knowledge mapping guided by data mining: application on healthcare", Journal of Information Processing Systems, Vol 9 No 1, pp. $1-30$

Becerra-Fernandez, I. and Sabherwal, R. (2006), "ICT and knowledge management systems", in Schwartz, D. (Ed.), Encyclopedia of Knowledge Management, IGI Global, New York, NY, pp. 230-236.

Bhamra, N., Gupta, K., Lee, J., Al-Hity, S., Jolly, K. and Darr, A., (2021), "Personal protective equipment: knowledge of the guidance", British Journal of Nursing, Vol 30 No 1, pp.16-22.

Buheji, M. and Buhaid, N. (2020), "Capturing Accumulated Knowledge and Learning of COVID-19 Pandemic from Front-Line Nurse", Human Resource Management Research, Vol 10 No 2, pp.27-32. 
Burnett, S., Illingworth, L. and Webster, L., (2004), "Knowledge auditing and mapping: a pragmatic approach", Knowledge and Process Management, Vol 11 No 1, pp.25-37.

Caputo, F., Garcia-Perez, A., Cillo, V. and Giacosa, E., (2019), “A knowledge-based view of people and technology: directions for a value co-creation-based learning organisation”, Journal of Knowledge Management, Vol 23 No 7, pp. 1314-1334.

Carayannis, E.G., Grigoroudis, E., Del Giudice, M., Della Peruta, M.R. and Sindakis, S., (2017), "An exploration of contemporary organizational artifacts and routines in a sustainable excellence context”, Journal of Knowledge Management, Vol 21 No 1, pp. 35-56.

Cargnel, M., Bianchini, J., Welby, S., Koenen, F., Van der Stede, Y., De Clercq, K. and Saegerman, C., (2021), "Improving laboratory diagnostic capacities of emerging diseases using knowledge mapping”, Transboundary and emerging diseases, Vol 68 No 3, pp.1175-1189.

Casella, F., (2021), "Can the COVID-19 epidemic be controlled on the basis of daily test reports? IEEE Control Systems Letters, Vol 5 No 3, pp.1079-1084.

Castaneda, D.I., Manrique, L.F. and Cuellar, S., (2018), "Is organizational learning being absorbed by knowledge management? A systematic review", Journal of Knowledge Management, Vol 22 No 2, pp.299-325.

Centers for Medicare and Medicaid services (CMS) (2020), "Toolkit on State Actions to Mitigate COVID-19 Prevalence in Nursing Homes", Version 6. [Online]. [Accessed 20 Aug 2020]. Available at: $<$ https://www.cms.gov/files/document/covid-toolkit-states-mitigatecovid-19-nursing-homes.pdf $>$.

Chaudhuri, R., Chavan, G., Vadalkar, S., Vrontis, D. and Pereira, V. (2020), "Two-decade bibliometric overview of publications in the Journal of Knowledge Management", Journal of Knowledge Management, Vol 25 No 6, pp. 1550-1574.

Chellamuthu, G. and Muthu, S., (2020), "Pandemic response protocol of a non-frontline specialty in a multispecialty tertiary health care centre - a pilot model in orthopaedics", International Orthopaedics, Vol 44, pp.1481-1487.

Chen, H., Chiang, R. and Storey, V. (2012), "Business intelligence and analytics: from big data to big impact”, MIS Quarterly, Vol 36 No 4, pp. 1165-1188.

Daňa, J., Caputo, F. and Ráček, J., (2020), "Complex network analysis for knowledge management and organizational intelligence", Journal of the Knowledge Economy, Vol 11 No 2, pp.405-424.

Das, T.K. and Kumar, R. (2007), "Learning dynamics in the alliance development process", Management Decision”, Vol 45 No 4, pp. 684--707.

Davenport, T.H. and Prusak, L., (1998), “Working knowledge: How organizations manage what they know”, Harvard Business School Press, Boston, MA. 
Del Giudice, M. and Maggioni, V. (2014), "Managerial practices and operative directions of knowledge management within inter-firm networks: a global view", Journal of Knowledge Management, Vol 18 No 5, pp. 841-846.

Department of Health and Social Care (DHSC) (2020), "COVID-19: Guidance for infection prevention and control in healthcare settings", Version 1.1, 27/03/20. [Online]. [Accessed 25 Aug 2020]. Available at:< https://nhsprocurement.org.uk/prevention-of-infections/>.

Despres, C. and Chauvel, D. (2000), "Knowledge horizons: the present and promise of knowledge management", Butterworth-Heinemann.

Drucker, P. F. (1988), The coming of the new organization. Harvard Business Review, 66 (1), pp. 45-53.

Drucker, P.F. (1993), “Post-capitalist Society”, Butterworth-Heinemann, Oxford.

Elavarasan, R.M. and Pugazhendhi, R., (2020), "Restructured society and environment: A review on potential technological strategies to control the COVID-19 pandemic", Science of The Total Environment, pp.138858

European Union (EU). (2020), "Joint European Roadmap towards lifting COVID-19 containment measures. [Online]. [Accessed 22 Aug 2020]. Available at: <https://ec.europa.eu/info/sites/info/files/communication__a_european_roadmap_to_lifting_coronavirus_containment_measures_0.pdf $>$.

Ferreira, J., Fernandes, C. and Ratten, V. (2016), "A co-citation bibliometric analysis of strategic management research", Scientometrics, Vol 109 No 1, pp. 1-32.

Ferreira, J., Mueller, J. and Papa, A., (2018), "Strategic knowledge management: theory, practice and future challenges", Journal of Knowledge Management., Vol 24 No 2, pp.,121126.

Filius, R., De Jong, J.A. and Roelofs, E.C. (2000), "Knowledge management in the HRD office: a comparison of three cases", Journal of Workplace Learning, Vol 12 No 7, pp. 286295.

Frankson, R., Hueston, W., Christian, K., Olson, D., Lee, M., Valeri, L., Hyatt, R., Annelli, J. and Rubin, C., (2016), "One Health core competency domains", Frontiers in public health, Vol 4, pp.192.

Gombos, K., Herczeg, R., Erőss, B., Kovács, S.Z., Uzzoli, A., Nagy, T., Kiss, S., Szakács, Z., Imrei, M., Szentesi, A. and Nagy, A., (2021), "Translating scientific knowledge to government decision makers has crucial importance in the management of the COVID-19 pandemic", Population Health Management, Vol 24 No 1, pp.35-45.

Goniewicz, K., Khorram-Manesh, A., Hertelendy, A.J., Goniewicz, M., Naylor, K. and Burkle, F.M., (2020), "Current response and management decisions of the European Union to the COVID-19 outbreak: a review", Sustainability, Vol 12 No 09, pp.3838. 
Grant, R.M. (1996), “Toward a knowledge-based theory of the firm”, Strategic Management Journal, Vol 17, pp. 109-22.

Gupta, B., Iyer, L.S. and Aronson, J.E., (2000), "Knowledge management: practices and challenges", Industrial management \& data systems. Vol 100 No 1, pp. 17-21.

Hart, O.E. and Halden, R.U., (2020), "Computational analysis of SARS-CoV-2/COVID-19 surveillance by wastewater-based epidemiology locally and globally: Feasibility, economy, opportunities and challenges", Science of The Total Environment, pp.138875.

Heisig, P., Suraj, O.A., Kianto, A., Kemboi, C., Perez Arrau, G. and Fathi Easa, N. (2016), "Knowledge management and business performance: global experts' views on future research needs", Journal of Knowledge Management, Vol 20 No 6, pp. 1169-1198.

Heldal, F., Kongsvik, T. and Håland, E., (2019), "Advancing the status of nursing: reconstructing professional nursing identity through patient safety work", BMC health services research, Vol 19 No 1), pp.418.

Holmgren, A.J., Apathy, N.C. and Adler-Milstein, J., (2020), "Barriers to hospital electronic public health reporting and implications for the COVID-19 pandemic", Journal of the American Medical Informatics Association, Vol 27 No 8, pp.1306-1309.

Hossain, M.M., (2020), "Current status of global research on novel coronavirus disease (Covid19): A bibliometric analysis and knowledge mapping. Hossain MM. Current status of global research on novel coronavirus disease (COVID-19): a bibliometric analysis and knowledge mapping.

Iandolo, F., Loia, F., Fulco, I., Nespoli, C., \& Caputo, F. (2020), "Combining Big Data and Artificial Intelligence for Managing Collective Knowledge in Unpredictable EnvironmentInsights from the Chinese Case in Facing COVID-19. Journal of the Knowledge Economy, pp. $1-15$.

Ibn-Mohammed, T., Mustapha, K.B., Godsell, J.M., Adamu, Z., Babatunde, K.A., Akintade, D.D., Acquaye, A., Fujii, H., Ndiaye, M.M., Yamoah, F.A. and Koh, S.C.L., (2021), “A critical review of the impacts of COVID-19 on the global economy and ecosystems and opportunities for circular economy strategies", Resources, Conservation and Recycling, Vol 164, pp.105169.

Islam, M.S., Rahman, K.M., Sun, Y., Qureshi, M.O., Abdi, I., Chughtai, A.A. and Seale, H., (2020), "Current knowledge of COVID-19 and infection prevention and control strategies in healthcare settings: A global analysis. Infection Control \& Hospital Epidemiology, Vol 41 No 10, pp.1196-1206.

Jallow, H., Renukappa, S., and Suresh, S. (2020), "The impact of COVID-19 outbreak on United Kingdom infrastructure sector", Smart and Sustainable Built Environment. [Online]. [Accessed 20 Jan 2021]. Available at: $<$ https://doi.org/10.1108/SASBE-05-2020-0068>.

Jennex, M.E., Smolnik, S. and Croasdell, D.T., (2009), "Towards a consensus knowledge management success definition", Vine, Vol 39 No 2, pp. 174-188. 
Kebede, G. (2010), "Knowledge management: an information science perspective", International Journal of Information Management, Vol 30 No 5, pp. 416-424.

Khowaja, S.A., Dev, K. and Khuwaja, P., (2021), "Internet of Everything enabled solution for COVID-19, its new variants and future pandemics: Framework, Challenges, and Research Directions", arXiv preprint arXiv:2101.02030.

Kim, S., Suh, E. and Hwang, H. (2003), "Building the knowledge map: an industrial case study", Journal of Knowledge Management, Vol 7 No 2, pp. 34-45.

Kruesi, L., Burstein, F. and Tanner, K. (2020), "A knowledge management system framework for an open biomedical repository: communities, collaboration and corroboration", Journal of Knowledge Management, Vol 24 No 10, pp. 2553-2572.

Kummitha, R.K.R., (2020), "Smart technologies for fighting pandemics: The techno-and human-driven approaches in controlling the virus transmission", Government Information Quarterly, pp.101481. [Online]. [Accessed 05 ${ }^{\text {th }}$ May 20]. Available at: $<$ https://www.sciencedirect.com/science/article/pii/S0740624X20301003>.

La Marca, A., Capuzzo, M., Paglia, T., Roli, L., Trenti, T. and Nelson, S.M., (2020), "Testing for SARS-CoV-2 (COVID-19): a systematic review and clinical guide to molecular and serological in-vitro diagnostic assays", Reproductive biomedicine online. Vol 41 No 3, pp. 483499.

Lee, Y., Tao, W., Li, J.-Y.Q. and Sun, R. (2021), "Enhancing employees' knowledge sharing through diversity-oriented leadership and strategic internal communication during the COVID19 outbreak", Journal of Knowledge Management, Vol 25 No 6, pp. 1526-1549.

Liang, C., Luo, A. and Zhong, Z., (2018), "Knowledge mapping of medication literacy study: a visualized analysis using CiteSpace", SAGE open medicine, Vol 6, pp.2050312118800199.

Liebowitz, J., Rubenstein-Montano, B., McCaw, D., Buchwalter, J., Browning, C., Newman, B. and Rebeck, K., (2000), "The knowledge audit", Knowledge and process management, Vol 7 No 1, pp.3-10.

Malhotra, Y. (2005), "Integrating knowledge management technologies in organizational business processes: getting real time enterprises to deliver real business performance", Journal of Knowledge Management, Vol 9 No 1, pp. 7-28.

Malik, A., Froese, F.J. and Sharma, P., (2020), "Role of HRM in knowledge integration: Towards a conceptual framework", Journal of Business Research, Vol 109, pp.524-535.

Manesh, M.F., Pellegrini, M.M., Marzi, G. and Dabic, M., (2020), "Knowledge management in the fourth industrial revolution: Mapping the literature and scoping future avenues", IEEE Transactions on Engineering Management, Vol 68 No 1, pp.289-300.

McAfee, A. and Brynjolfsson, E. (2012), "Big data: the management revolution", Harvard Business Review, Vol 90 No 10, pp. 60-68. 
McIntosh, K., Hirsch, M.S. and Bloom, A., (2020), "Coronavirus disease 2019 (COVID19). UpToDate Hirsch MS Bloom, Vol 5, pp.1-1

Mehreen, H., Rammal, H. G., Pereira, V., \& Del Giudice, M. (2021), "Investigating the influence of absorptive capacity of recipients within the cross-border transfer of knowledge: evidence from emerging markets", International Marketing Review. https://opus.lib.uts.edu.au/bitstream/10453/148219/3/Investigating\%20the\%20Influence\%20 of\%20Absorptive \%20Capacity\%20of\%20Recipients.pdf

Michailova, S. and Nielsen, B.B., (2006), "MNCs and knowledge management: a typology and key features", Journal of Knowledge Management, Vol 10 No 1, pp. 44-54.

Mital, M., Del Giudice, M. and Papa, A., (2018), "Comparing supply chain risks for multiple product categories with cognitive mapping and Analytic Hierarchy Process", Technological Forecasting and Social Change, Vol 131, pp.159-170.

Monteiro, F.L., Arvidson, N. and Birkinshaw, J. (2008), "Knowledge flows within multinational corporations: explaining subsidiary isolation and its performance implications", Organization Science, Vol 19 No 1, pp. 90-107.

Moradi, R., Taheri, K. and Mirian, M.S., (2017), "Data-driven methods to create knowledge maps for decision making in academic contexts", Journal of Information \& Knowledge Management, Vol 16 No 01, p.1750008.

Moreira, M.W., Rodrigues, J.J., Korotaev, V., Al-Muhtadi, J. and Kumar, N., (2019), "A comprehensive review on smart decision support systems for health care", IEEE Systems Journal, Vol 13 No 3, pp.3536-3545.

Mortazavi, A., Mortazavi, S.M.J. and Sihver, L., (2021), "Selective Pressure-Free Treatments for COVID-19”, Radiation, Vol 1 No 1, pp.18-32.

Natalicchio, A., Ardito, L., Savino, T., \& Albino, V. (2017), "Managing knowledge assets for open innovation: A systematic literature review", Journal of Knowledge Management, Vol 21 No 6, pp. 1362.

Nathavitharana, R.R., Patel, P.K., Tierney, D.B., Mehrotra, P., Lederer, P.A., Davis, S. and Nardell, E., (2020), "Innovation and Knowledge Sharing Can Transform COVID-19 Infection Prevention Response", Journal of hospital medicine, Vol 15 No 5, pp.299-301.

Nguyen, H.L., Vu, D.T. and Jung, J.J., (2020), “Knowledge graph fusion for smart systems: A Survey", Information Fusion, Vol 61, pp. 56-70.

Nonaka, I. and Takeuchi, H. (1995), "The Knowledge-Creating Company: How Japanese Companies Create the Dynamics of Innovation", Oxford University Press, New York, NY.

Obeso, M., Hernandez-Linares, R., Lopez-Fernandez, M.C. and Serrano-Bedia, A.M. (2020), "Knowledge management processes and organizational performance: the mediating role of organizational learning”, Journal of Knowledge Management, Vol 24 No 8, pp. 1859-1880. 
Papa, A., Mital, M., Pisano, P. and Del Giudice, M., (2020), "E-health and wellbeing monitoring using smart healthcare devices: An empirical investigation", Technological Forecasting and Social Change, Vol 153, pp.119226.

Parra, C.M., Gupta, M. and Mikalef, P., (2021), "Information and communication technologies (ICT)-enabled severe moral communities and how the (Covid19) pandemic might bring new ones", International Journal of Information Management, Vol 57, p.102271.

Polanyi, M., (1966), “The Tacit Dimension”, Routledge and Kegan Paul, London.

Public Health England (PHE) (2021), "COVID-19: Guidance for maintaining services within health and care settings: Infection prevention and control recommendations", [Online].

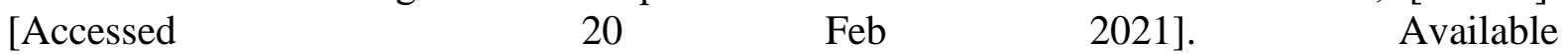
at: $<$ https://assets.publishing.service.gov.uk/government/uploads/system/uploads/attachment data/file/954690/Infection_Prevention_and_Control_Guidance_January_2021.pdf $>$.

Schwerdtle, P.N., Connell, C.J., Lee, S., Plummer, V., Russo, P.L., Endacott, R. and Kuhn, L., (2020), "Nurse Expertise: A Critical Resource in the COVID-19 Pandemic Response", Annals of Global Health, Vol 86 No 1.

Skyrme, D. J. and Amidon, D. M. (1997), "The Knowledge Agenda. Journal of Knowledge Management", Vol 1 No 1, 27-37.

Speel, P. H., Shadbolt, N., de Vries, W., Van Dam, P. H. and O’Hara, K. (1999), “Knowledge mapping for industrial purposes 12th Workshop on Knowledge Acquisition”, Modelling and Management.

Ramona, T. and Alexandra, B., (2019), "Knowledge Retention within Small and Mediumsized Enterprises", Studies in Business and Economics, Vol 14 No 3, pp.231-238.

Renukappa, S. and Egbu, C. (2007), "The key challenges associated with mapping sustainability-related knowledge for organisational competitiveness: an empirical study", Information and Knowledge Management-Helping the Practitioner in Planning and Building, Stuttgart, Fraunhofer IRB Verlag, pp.335-344.

Rialti, R., Marzi, G., Caputo, A. and Mayah, K.A., (2020), “Achieving strategic flexibility in the era of big data: The importance of knowledge management and ambidexterity. Management Decision. Vol 58 No 8, pp. 1585-1600.

Rowan, N.J. and Laffey, J.G., (2020), "Challenges and solutions for addressing critical shortage of supply chain for personal and protective equipment (PPE) arising from Coronavirus disease (COVID19) pandemic-Case study from the Republic of Ireland", Science of The Total Environment, pp.138532.

Santoro, G., Bresciani, S., \& Papa, A. (2020), "Collaborative modes with cultural and creative industries and innovation performance: the moderating role of heterogeneous sources of knowledge and absorptive capacity", Technovation, Vol 92, pp. 102040. https://wwwsciencedirect-com.ezproxy.wlv.ac.uk/science/article/pii/S016649721730398X 
Scuotto, V., Del Giudice, M., \& Carayannis, E. G. (2017), "The effect of social networking sites and absorptive capacity on SMES' innovation performance", The Journal of Technology Transfer, Vol 42 No 2, pp. 409-424. com.ezproxy.wlv.ac.uk/content/pdf/10.1007/s10961-016-9517-0.pdf

Sensuse, D.I. and Hakim, S.A., (2019), "Building smart knowledge mapping conceptual model”, Journal of Information \& Knowledge Management, Vol 18 No 02, p.1950021.

Shi, F., Wang, J., Shi, J., Wu, Z., Wang, Q., Tang, Z., He, K., Shi, Y., and Shen, D., (2021), "Review of artificial intelligence techniques in imaging data acquisition, segmentation and diagnosis for COVID-19”, in IEEE Reviews in Biomedical Engineering, Vol 14, pp.4-15.

Singh, S. K., Del Giudice, M., Nicotra, M., \& Fiano, F. (2020), "How Firm Performs Under Stakeholder Pressure: Unpacking the Role of Absorptive Capacity and Innovation Capability", IEEE Transactions on Engineering Management. https://ieexplore-ieeeorg.ezproxy.wlv.ac.uk/stamp/stamp.jsp?tp=\&arnumber=9289009.

Snyder, H., (2019), "Literature review as a research methodology: An overview and guidelines", Journal of Business Research, Vol 104, pp.333-339.

Spinelli, A. and Pellino, G., (2020), "COVID-19 pandemic: perspectives on an unfolding crisis. Journal of British Surgery”, Vol 107 No 7, pp.785-787.

Stirling, A.C. and Scoones, I., (2009), "From risk assessment to knowledge mapping: science, precaution, and participation in disease ecology", Ecology and Society, Vol 14 No 2.

Storey, J. and Barnett, E. (2000), "Knowledge management initiatives: learning from failure", Journal of Knowledge Management, Vol 4 No 2, 145-156.

Sturm, A., Gross, D., Wang, J. e Yu, E. (2017), "Means-end based know-how mapping", Journal of Knowledge Management, Vol. 21 No 2, pp. 454-473

Suresh, S. and Egbu, C.O. (2008), "Knowledge mapping techniques within the construction industry: an exploratory study". CIB W102-Information and knowledge management in Buildings, pp.48-57.

Swanson, D., and Santamaria, L. (2021), "Pandemic Supply Chain Research: A structured Literature Review and Bibilimetric Network Analysis", Logistics, Vol 5 No 1, p.7.

Tranfield, D., Denyer, D. and Smart, P. (2003), "Towards a methodology for developing evidence-informed management knowledge by means of systematic review", British journal of management, Vol 14 No 3, pp.207-222.

Vaishya, R., Javaid, M., Khan, I.H. and Haleem, A. (2020), "Artificial Intelligence (AI) applications for COVID-19 pandemic", Diabetes \& Metabolic Syndrome: Clinical Research \& Reviews. Vol 14 No 4, pp. 337-339.

Vasudeva, G., Spencer, J.W. and Teegen, H.J. (2013), "Bringing the institutional context back in: a cross-national comparison of alliance partner selection and knowledge acquisition", Organization Science, Vol 24 No 2, pp. 319-338. 
Vimal, R. and Morgans, C. (2020), "Using knowledge mapping to rethink the gap between science and action", Conservation Biology, Vol 34 No 6, pp.1433-1443.

Wamba, S.F., Gunasekaran, A., Akter, S., Ren, S.J.F., Dubey, R. and Childe, S.J. (2017), "Big data analytics and firm performance: Effects of dynamic capabilities", Journal of Business Research, Vol 70, pp.356-365.

Wang, F.Y. (2012), "A big-data perspective on AI: Newton, Merton, and analytics intelligence", IEEE Intelligent Systems, Vol 27 No 5, pp. 2-4.

Wang, W.T. and Wu, S.Y., (2020), "Knowledge management based on information technology in response to COVID-19 crisis", Knowledge Management Research \& Practice, pp.1-7.

Watthananon, J. and Mingkhwan, A., (2012), "Optimizing knowledge management using knowledge map", Procedia Engineering, Vol 32, pp.1169-1177.

Weintraub, R.L., Subramanian, L., Karlage, A., Ahmad, I. and Rosenberg, J., (2021), “COVID19 Vaccine To Vaccination: Why Leaders Must Invest In Delivery Strategies Now: Analysis describe lessons learned from past pandemics and vaccine campaigns about the path to successful vaccine delivery for COVID-19”, Health Affairs, pp.10-1377.

Wexler, M.N., (2001), "The who, what and why of knowledge mapping", Journal of knowledge management, Vol 5 No 3, pp. 249-264.

Wiig, K., (1997), "Integrating intellectual capital and knowledge management", Long Range Planning, Vol 30 No 3, pp. 399-405.

World Health Organisation (WHO) (2020), "WHO Coronavirus Disease (COVID-19) Dashboard", [Online]. [Accessed 20 Aug 2020]. Available at: $<$ https://covid19.who.int $>$.

Wu, S., Wang, Y., Jin, X., Tian, J., Liu, J. and Mao, Y., (2020a), "Environmental contamination by SARS-CoV-2 in a designated hospital for coronavirus disease 2019", American journal of infection control, Vol 48 No 8, pp.910-914.

Yang, R., Du, G., Duan, Z., Du, M., Miao, X. and Tang, Y., (2020), "Knowledge system analysis on emergency management of public health emergencies", Sustainability, Vol 12 No 11, p.4410.

Yasin, F. and Egbu, C., (2011), "Critical steps to knowledge mapping in facilities management organisation". In 27th annual ARCOM conference (pp. 603-612).

Younan, M., Houssein, E.H., Elhoseny, M. and Ali, A.A., (2020), "Challenges and recommended technologies for the industrial internet of things: A comprehensive review”, Measurement, Vol 151, p.107198.

Zack, M.H. (2002), "Developing a knowledge strategy", California Management Review, Vol 41 No 3, pp. 125-223. 
Zammuto, R.F., Griffith, T.L., Majchrzak, A., Dougherty, D.J. and Faraj, S. (2007), "Information technology and the changing fabric of organization", Organization Science, Vol 18 No 5, pp. 749-762.

Zhou, C., Su, F., Pei, T., Zhang, A., Du, Y., Luo, B., Cao, Z., Wang, J., Yuan, W., Zhu, Y. and Song, C., (2020a), "COVID-19: Challenges to GIS with big data", Geography and Sustainability, Vol. 1 No. 1, pp. 77-87.

Zhou, J., Otter, J.A., Price, J.R., Cimpeanu, C., Garcia, D.M., Kinross, J., Boshier, P.R., Mason, S., Bolt, F., Holmes, A.H. and Barclay, W.S., (2020b), "Investigating SARS-CoV-2 surface and air contamination in an acute healthcare setting during the peak of the COVID-19 pandemic in London", Clinical Infectious Diseases. [Online]. [Accessed 20 Feb 2021]. Available at: $<$ https://doi.org/10.1093/cid/ciaa905 $>$.

Zhou, X., Mulay, A., Ferrara, E. and Zafarani, R., (2020c), "ReCOVery: A Multimodal Repository for COVID-19 News Credibility Research", arXiv preprint arXiv:2006.05557. 